Mississippi State University

Scholars Junction

8-10-2018

\title{
Early impacts of midstory hardwoods and overstory density on longleaf seedling establishment on xeric sites
}

Jacob Colin Henry

Follow this and additional works at: https://scholarsjunction.msstate.edu/td

\section{Recommended Citation}

Henry, Jacob Colin, "Early impacts of midstory hardwoods and overstory density on longleaf seedling establishment on xeric sites" (2018). Theses and Dissertations. 5056.

https://scholarsjunction.msstate.edu/td/5056

This Graduate Thesis - Open Access is brought to you for free and open access by the Theses and Dissertations at Scholars Junction. It has been accepted for inclusion in Theses and Dissertations by an authorized administrator of Scholars Junction. For more information, please contact scholcomm@msstate.libanswers.com. 
Early impacts of midstory hardwoods and overstory density on longleaf seedling

establishment on xeric sites

By

Jacob Colin Henry

\author{
A Thesis \\ Submitted to the Faculty of \\ Mississippi State University \\ in Partial Fulfillment of the Requirements \\ for the Degree of Master of Science \\ in Forestry \\ in the Department of Forestry
}

Mississippi State, Mississippi

August 2018 
Copyright by

Jacob Colin Henry

2018 
Early impacts of midstory hardwoods and overstory density on longleaf seedling establishment on xeric sites

By

Jacob Colin Henry

Approved:

John L. Willis

(Major Professor)

Heather D. Alexander

(Committee Member)

Heidi J. Renninger

(Committee Member)

Scott D. Roberts

(Committee Member)

Andrew W. Ezell

(Graduate Coordinator)

George M. Hopper

Dean

College of Forest Resources 
Name: Jacob Colin Henry

Date of Degree: August 10, 2018

Institution: Mississippi State University

Major Field: Forestry

Major Professor: John L. Willis

Title of Study: Early impacts of midstory hardwoods and overstory density on longleaf seedling establishment on xeric sites

Pages in Study 69

Candidate for Degree of Master of Science

Competition from hardwood species has long been considered a constraint on longleaf pine (Pinus palustris). However, evidence suggests that hardwood midstories may improve longleaf regeneration on xeric sites. Additionally, overstory retention for red-cockaded woodpecker (Leuconotopicus borealis; RCW) habitat may be inadvertently contributing to regeneration failures. Experimental plots in the North Carolina Sandhills were planted with containerized longleaf seedlings across a gradient of overstory density, and hardwoods were chemically controlled by treating at planting, treating after one year, or left untreated. Seedling survival (percent), growth (mass), and brown spot needle blight (percent infected seedlings; BSNB) were measured after two years. Seedling survival, growth, and BSNB infection rates were inversely related to overstory density. Midstory treatments did not significantly affect seedling survival, growth, or BSNB infection rates. Early results did not show facilitative effects from a hardwood midstory, but indicated overstory densities greater than $12 \mathrm{~m}^{2} /$ ha negatively impact longleaf regeneration. 


\section{DEDICATION}

"We abuse land because we regard it as a commodity belonging to us. When we see land as a community to which we belong, we may begin to use it with love and respect."

- Aldo Leopold 


\section{ACKNOWLEDGEMENTS}

I would first like to thank my thesis advisor Dr. John Willis for his continuous guidance and support throughout my master's. I would also like to thank my committee members for their support and wide range of expertise: Dr. Heather Alexander, Dr. Heidi Renninger, and Dr. Scott Roberts. I also thank David Schnake, North Carolina Forest Research Operations Manager, for his incredible on-site support and dedication to the project.

I would also like to thank the Mississippi State University Department of Forestry for making this research possible, and for providing my assistantship. Additionally, I would like to thank the North Carolina Department of Agriculture and Consumer Services for operational funding. 


\section{TABLE OF CONTENTS}

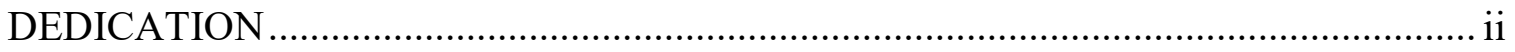

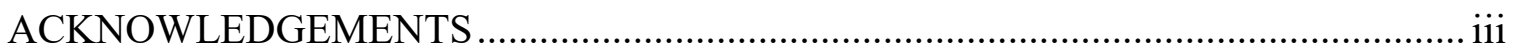

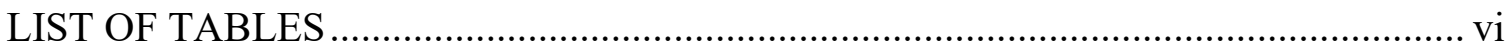

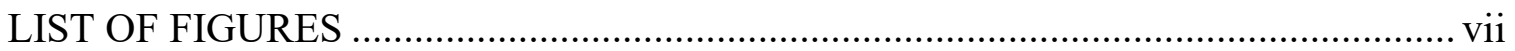

\section{CHAPTER}

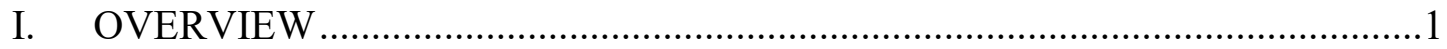

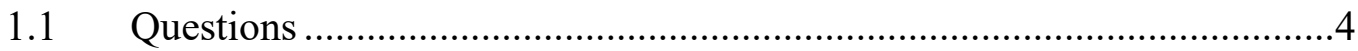

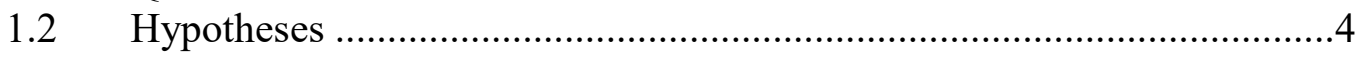

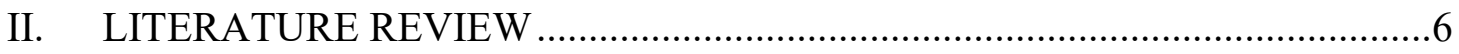

2.1 Longleaf Range and Life History Traits.....................................................6

2.2 Decline of Longleaf Pine ....................................................................

$2.3 \quad$ Ecological Implications .........................................................................10

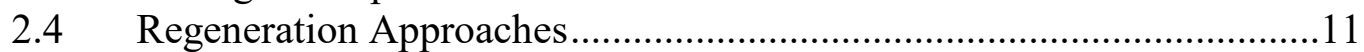

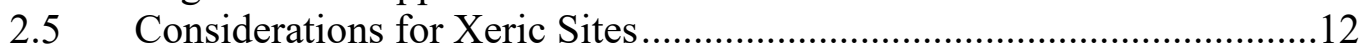

2.6 Competition and Facilitation ................................................................... 14

2.7 Competition and Facilitation in the Longleaf Ecosystem .........................15

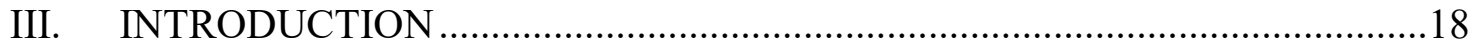

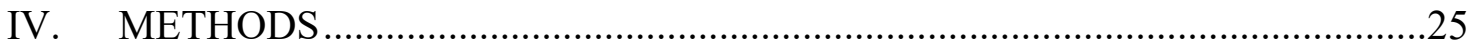

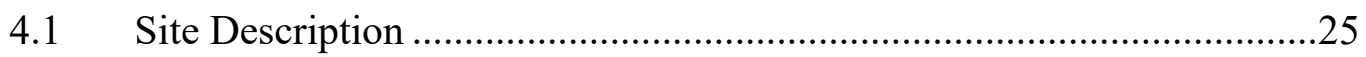

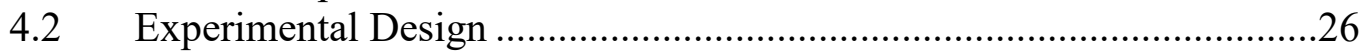

4.3 Sampling Design ..........................................................................29

4.4 Statistical Analysis .........................................................................

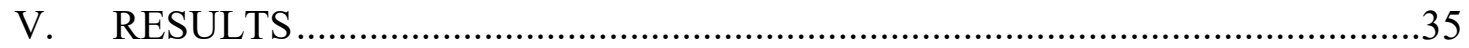

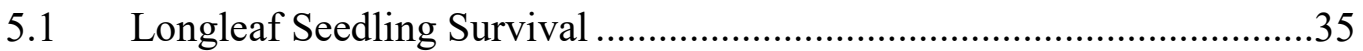

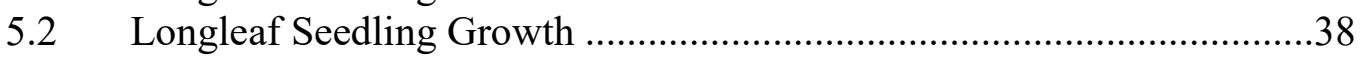

5.3 Brown Spot Needle Blight Infection .....................................................40 


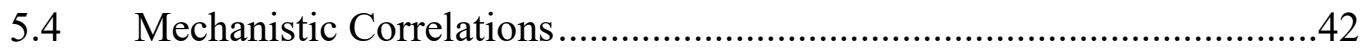

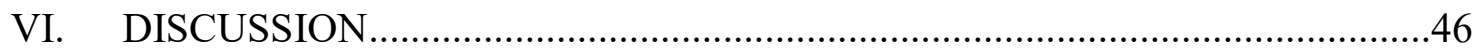

6.1 RCW Overstory Management Guidelines ...........................................46

6.2 Midstory Treatments ......................................................................48

6.3 Mechanistic Correlations .................................................................. 51

VII. MANAGEMENT IMPLICATIONS .......................................................... 55

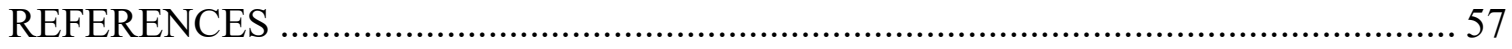
APPENDIX

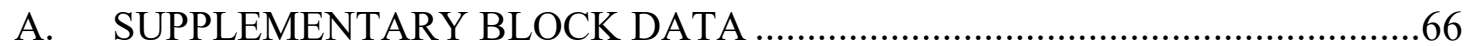




\section{LIST OF TABLES}

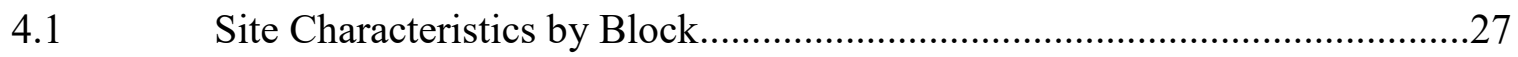

5.1 Type 3 Tests of Fixed Effects in Best Model for All Response

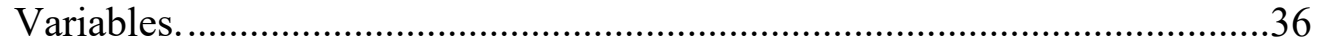

5.2 Pearson Correlation Analyses for Growth Metrics. .....................................38

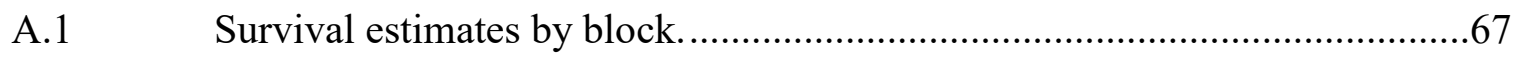

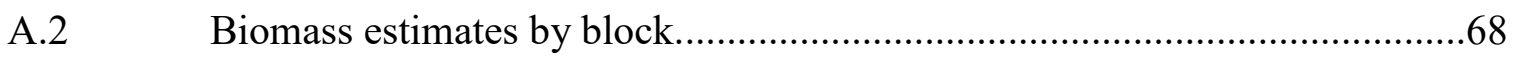

A.3 BSNB infection estimates by block..................................................69 


\section{LIST OF FIGURES}

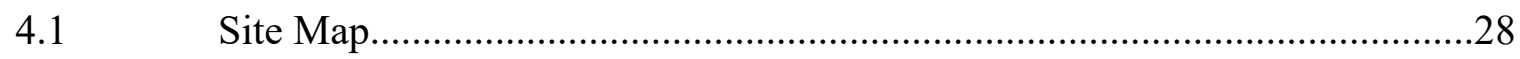

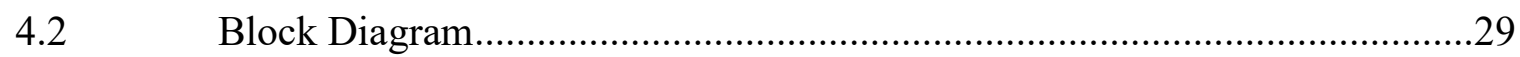

5.1 Survival Response to Fixed Effects............................................................37

5.2 Biomass Response to Fixed Effects. ………….............................................39

5.3 Brown Spot Needle Blight Infection Response to Fixed Effects. ...................41

5.4 Pearson Correlation Analyses for Moisture Dynamics. ..................................43

5.5 Pearson Correlation Analyses for Light Dynamics.........................................45 


\section{CHAPTER I}

\section{OVERVIEW}

The longleaf pine (Pinus palustris Mill.) ecosystem is recognized as one of the most unique and dynamic ecosystems in North America (Van Lear et al. 2005). Among its many desirable characteristics, the longleaf ecosystem provides habitat for a diverse array of flora and fauna (Noss et al. 1995), as well as serving as a valuable timber resource since European settlement (Frost 1993). Unfortunately, the future of the longleaf ecosystem is currently threatened (Noss et al. 1995). Once dominant on 38 million hectares across the southeastern Coastal Plain, the longleaf ecosystem has been reduced to less than two percent of its historical range (Outcalt \& Sheffield 1996). This reduction began with exploitative harvesting from the timber and naval stores industries in the 1800’s, limiting longleaf seed source availability (Frost 1993). Regeneration was subsequently suppressed due to implementation of fire suppression policies (as longleaf is a fire-dependent species) (Wade \& Lundsford 1989), browsing from feral hogs (Sus scrofa Linn.; Mayer et al. 2000), and conversion to faster growing timber species such as loblolly pine (Pinus taeda Linn.) and slash pine (Pinus elliottii Engelm.) (Frost 1993).

Due to a growing recognition of the importance of the longleaf pine ecosystem, interest in longleaf pine restoration has increased dramatically since the late 1970's (U.S. Fish and Wildlife Service 2003, first version 1979). However, while artificial regeneration has made drastic improvements (Jose et al. 2006), achieving natural 
regeneration of longleaf pine remains an inconsistent goal (Brockway et al. 2006, Gagnon et al. 2004). Some of the more consistent issues for longleaf regeneration since the fire suppression era have been increased competition from overstory longleaf pines (Brockway \& Outcalt 1998), light limitation due to the presence of midstory hardwoods (Van Lear et al. 2005), competition with other, faster growing, fire sensitive pine species such as loblolly and slash pine (Outcalt 2000), and the fungal pathogen brown spot needle blight (Scirrhia acicola, Dearn.; BSNB; Kais 1975).

In many situations, longleaf regeneration must also be balanced with additional natural resource objectives. For example, managing mature longleaf stands for redcockaded woodpecker (Leuconotopicus borealis Vieillot; RCW) habitat has become a common management objective (Hiers et al. 2014). RCW is an endangered bird found in the longleaf ecosystem that prefers large diameter trees for cavities (Rudolph \& Conner 1991) and large longleaf forests for foraging (Henry 1989). While management practices for RCW habitat are similar to traditional longleaf regeneration practices (such as maintaining a hardwood midstory below $2 \mathrm{~m}$ ), some potentially important differences do exist (such as retaining higher overstory density for RCW habitat), bringing the compatibility of these management objectives into question.

Another potentially problematic feature of RCW management for longleaf regeneration is the practice of controlling midstory hardwoods. Although this practice is consistent with traditional longleaf regeneration practices, as hardwoods have been shown to be inhibitory to longleaf regeneration on some sites (Brockway et al. 2006, Provencher et al. 2001), a growing body of evidence suggests that midstory hardwoods may facilitate the survival of newly established seedlings on xeric sites (Wahlenberg 
1946, Espeleta et al. 2004, Loudermilk et al. 2016). This suggests that current management practices may be inhibiting longleaf regeneration in some parts of its geographic range.

The mechanisms by which midstory hardwoods facilitate longleaf regeneration on xeric sites has not been thoroughly investigated. Potential mechanisms of note include alleviation of moisture stress through shading during the growing season, and hydraulic redistribution of water to the upper soil profile (Espeleta et al. 2004). Currently, there is a lack of understanding of how midstory hardwoods affect longleaf regeneration across a gradient of overstory density, and how this relationship functions mechanistically. Clarifying the mechanisms and temporal aspects of the relationship between overstory, midstory, and understory is of great importance for the restoration and management of the longleaf ecosystem, as current RCW management efforts that remove midstory hardwoods prior to longleaf seedling establishment may be inadvertently contributing to regeneration failures on xeric sites.

My study aims to address these issues by quantifying the effects of variable overstory density and the presence of midstory hardwoods on longleaf pine seedling survival and growth on a xeric site. Additionally, a suite of biotic and abiotic factors was assessed to gain a better understanding of the mechanisms present, and how they may change in response to variable overstory density and the presence or absence of midstory hardwoods. The results of this research will help to better inform future management decisions regarding longleaf pine regeneration. 


\subsection{Questions}

1. Does managing overstory density for RCW habitat negatively affect longleaf pine seedling survival, growth, and BSNB infection?

2. Does the presence of midstory hardwoods have a positive, negative, or neutral effect on longleaf pine seedling growth, survival, and BSNB infection rates?

3. Do the facilitative interactions between midstory hardwoods and longleaf pine seedlings, if present, shift to competitive within the timespan of two years?

4. Through what mechanisms are midstory hardwoods facilitating longleaf pine seedlings?

\section{$1.2 \quad$ Hypotheses}

1. Overstory Density

- Longleaf pine seedling survival and growth will decrease with increasing overstory density.

- The infection rate of BSNB will decrease with increasing overstory density, as the pathogen prefers higher levels of light.

2. Midstory Treatments

- The presence of a midstory will have a positive effect on longleaf pine seedling survival.

- The presence of a midstory will have a negative effect on longleaf pine seedling growth.

- The presence of a midstory will have a negative effect on BSNB infection rates.

3. Facilitation Length 
- Longleaf pine seedling survival will be greatest underneath the midstory that was retained for the entirety of the experiment.

- Seedling growth will be greatest when the midstory is removed after one year. The first year will provide a facilitative effect, and removal will provide elevated light levels for increased growth and prevent this relationship from switching to a competitive one.

- BSNB infection rates will be highest when no midstory is present, due to elevated light levels.

4. Mechanistic Responses

- Moisture availability will correlate negatively to overstory density and midstory presence, and positively to seedling survival, growth, and physiological measurements (such as photosynthetic and transpiration rates) due to high moisture stress and competition for moisture on xeric sites.

- Understory light levels will correlate negatively to overstory density and midstory presence, and positively to BSNB infection rates, as the fungus prefers high light levels. Seedling growth and survival will not correlate strongly with light levels, due to the high light availability present at this site. 


\section{CHAPTER II}

\section{LITERATURE REVIEW}

\subsection{Longleaf Range and Life History Traits}

Once dominant over 30 million hectares, longleaf pine has the second largest natural range of any pine species in eastern North America (Frost 1993, Burns \& Honkala 1990). Within its geographic range, longleaf can be found growing under a variety of climatic conditions and as a component of several forest types. Although the abiotic conditions of longleaf occurrence are highly variable, frequent (two-to-five years), lowintensity surface fire has commonly been associated with longleaf occurrence due to the fire-promoting characteristics of the associated ground-layer flora and the fire-tolerating traits of longleaf pine (Brown 2000). Prior to European settlement (1600's), vast expanses of open woodlands were frequently ignited by lightning and cultural burning from Native Americans (Johnson \& Hale 2002). The resulting fires provided several essential services for longleaf regeneration including preventing competition associated with the establishment of fire sensitive species (Brockway \& Lewis 1997) and increasing availability of bare mineral soil, which is essential for longleaf germination and establishment (Burns \& Honkala 1990). The competitive success of the early successional, shade intolerant longleaf depends on this fire regime (Burns \& Honkala 1990), which is maintained as longleaf matures through fire-promoting traits of this species. 
Longleaf pine is well adapted for a frequent, low-intensity fire regime (Burns \& Honkala 1990). Unlike most other North American pine species, longleaf does not immediately initiate height growth after germination. Instead, longleaf allocates carbohydrates towards developing its root system and accumulating leaf area (Burns \& Honkala 1990). While in this stage (referred to as the grass stage), longleaf lacks a woody stem and resembles a clump of grass. The grass stage is a strategy of both resistance and resilience to fire. The investment in needle accumulation protects the terminal bud from fire (resistance), and belowground biomass accumulation allows for regrowth after fire (resilience). Seedlings that have exited the grass stage are somewhat susceptible to fire early in height growth, but are again fire resistant after attaining a height of approximately one meter (Burns \& Honkala 1990). Longleaf can survive in the grass stage for up to 10 years and will not initiate height growth until it has accumulated belowground resources with sufficient light availability (Fowells 1965).

As adults, longleaf actively promotes fire through the shedding of flammable needles (Grace \& Platt 1995). Mature longleaf also maintain fire resistance due to thick bark (Hare 1965). From these factors of fire resistance, resilience, and promotion, it logically follows that longleaf exists in a pyroclimax community. However, a combination of fire suppression policies and other anthropogenic factors have led to the endangerment of longleaf pine ecosystems.

\subsection{Decline of Longleaf Pine}

Surveys show that as of 1995 only 1.2 million hectares of the longleaf pine ecosystem remained, a 98\% reduction from the pre-European era (Outcalt \& Sheffield 1996). Several anthropogenic factors have contributed to the decline of the longleaf pine 
ecosystem. Longleaf was first sought by the naval stores industry for its high resin content used in turpentine production (Jose et al. 2006). To obtain the resin, trees were wounded (hereafter referred to as boxing) by cutting into the cambium to encourage resin flow. While boxing is not necessarily fatal, it does create a wound, which increases vulnerability to fungal pathogens or forest insects (Frost 1993). Wounded trees can also contribute to higher mortality in fire, as resin has been shown to increase fire intensity (Frost 1993). Boxing continued until the 1920's when the last of the virgin longleaf forests were depleted (Frost 1993).

Throughout the period of boxing, longleaf was exploitatively harvested for timber. During the European colonization of the Southeast in the 1730's, logging was limited to stands near rivers for transportation purposes. However, logging intensity increased dramatically with the onset of steam technology in the 1850's (Frost 1993). Steam technology allowed loggers to move felled trees to sawmills faster and more efficiently, opening up previously inaccessible areas for harvest. By 1884, the annual national cut of timber was reported at around 1.2 billion board feet (Sargent 1884), and increased to 3.7 billion board feet by 1896 (Mohr 1896).

Exploitative harvesting also had an unintended impact on the fire regime. The coarse and fine woody debris (hereafter referred to as slash) that was left behind after exploitative harvests led to a shift towards greater fire intensity (Wade \& Lundsford 1989). These harvesting practices not only added fuels, but also increased light availability which helped reduce fuel moisture. While longleaf is generally fire adapted, newly established seedlings are vulnerable to higher intensity surface fires (Boyer \& Peterson 1983). This increase in fire intensity could have killed many grass stage longleaf 
and saplings by burning off all the needles and damaging the terminal bud, and may have potentially killed some adult trees.

Increased fire intensity was not the only factor that contributed to the decline of longleaf, as several other factors severely impacted regeneration. The first of these was the loss of fire. A national policy of fire suppression was implemented from 1910 to 1930, which severely reduced longleaf regeneration due to seedlings being outcompeted for light (Frost 1993). Allocating resources to root development in the grass stage provides longleaf a degree of resistance to surface fire; however, in the absence of fire, belowground allocation becomes a liability in the competition for light (Gilliam \& Platt 1999, Pessin 1938). Additionally, slash pine and loblolly pine began being grown in plantations in the 1920 's, but came to prominence in the 1950's with nationwide reforestation efforts (Fox et al. 2007). Both slash and loblolly pine are more susceptible to fire as seedlings and saplings than longleaf pine (Frost 1993). The policy of fire suppression was then reinforced due to the high economic value of these pines. Longleaf's fire dependence is recognized today, but fire suppression occurred at a time when regeneration was desperately needed to restore longleaf populations after logging and turpentine production.

An increasingly important barrier to longleaf regeneration is the presence of feral hogs. Feral hogs were introduced to North America by European settlers in the mid1600 's, and their numbers dramatically increased within the geographic range of longleaf by 1750 (Frost 1993). Feral hogs are particularly problematic for longleaf regeneration because they preferentially browse longleaf seedlings for their high root carbohydrate content (Frost 1993). Two studies conducted on the effects of exclusion of feral hogs 
both showed drastically reduced numbers of longleaf pine seedlings when no fencing is in place compared to fenced areas (Lipscomb 1989, Mattoon 1922). Today, longleaf pine is amongst the most greatly impacted species by hog predation both spatially and economically (Mayer et al. 2000).

As a result of the above discussed anthropogenic factors, longleaf currently occupies $2 \%$ of its historical range (Jose et al. 2006). While regeneration of longleaf has been difficult due to a lack of seed sources and other challenges (fire suppression and feral hogs), progress is being made in restoring longleaf forests. The ecological implications of these factors can be seen today in both the flora and fauna of the longleaf ecosystem.

\subsection{Ecological Implications}

The historical reduction of the longleaf ecosystem has resulted in declining populations of many associated plant and animal species (Van Lear et al. 2005). Around 40 percent of the plant species in the Atlantic and Gulf coastal plains are restricted to the longleaf pine ecosystem; the majority of which are considered federally threatened or endangered (Walker 1998). This includes a diverse floral understory reliant on a frequent fire regime (Brockway \& Lewis 1997). The open savanna structure maintained by frequent surface fires promotes a variety of habitat conditions, which, in turn, leads to species diversity (Engstrom 1993). Two of the better known examples of species threatened by the decline of longleaf are the red-cockaded woodpecker and gopher tortoise (Gopherus polyphemus). While red-cockaded woodpeckers are not strictly endemic to longleaf (Doster \& James 1998), they are most closely adapted to the particular characteristics of longleaf pine's morphology: relatively high longevity, high 
resin content, and fire tolerance (Walters et al. 2002, Conner \& Rudolph 1995). The gopher tortoise is dependent on the frequent surface fire regime of the longleaf ecosystem to maintain adequate herbaceous vegetation to feed upon (Diemer 1986).

\subsection{Regeneration Approaches}

Light availability has long been recognized as the critical resource for longleaf regeneration (Pessin 1938, McGuire et al. 2001). Traditionally, foresters maintained high-light environments for longleaf regeneration through a seed-tree (20-25 seed trees per ha) or modified shelterwood system (basal area of $13.8-16.1 \mathrm{~m}^{2} / \mathrm{ha}$ ) (Mitchell et al. 2006, Walker 1995). These systems allow for sufficient seed sources due to limited dispersal (majority within $20 \mathrm{~m}$ ) and infrequent masting (every 6 to 15 years) (McClanahan 1986, Koenig \& Knops 1998). Mature longleaf left standing from these approaches also provide a source of fuel for surface fires. Following germination, prescribed fire is typically applied at 2-5 year intervals to control competition that arises from the increased light availability. When fire is not a feasible option, herbicides have been shown to be a viable alternative in reducing understory competition (Harrington et al. 1998).

Another challenge facing longleaf pine regeneration is brown spot needle blight. Brown spot needle blight is a native fungal pathogen that can delay growth and cause mortality, most commonly in the grass stage of development (Phelps et al. 1978). Experimental studies have shown that increases in light and humidity facilitate the infection of longleaf pine seedling needles due to stomata providing an opening for the fungus, and maximum infection occurs at temperatures similar to field conditions (i.e. 30 ${ }^{\circ} \mathrm{C}$ day and $21{ }^{\circ} \mathrm{C}$ night) (Kais 1975). Temperatures above and below this threshold 
resulted in reduced infection levels. Management recommendations include spraying fungicides, shelterwood management, and low-intensity prescribed fires (Phelps et al. 1978). Oftentimes, fire acts as a natural control of brown spot as it burns off infected needles.

The establishment of a hardwood midstory has long been thought to inhibit longleaf regeneration. Often developing in the absence of fire, midstory hardwoods have been shown to compete with longleaf seedlings for resources (Jose et al. 2006, Pecot et al. 2007), and therefore, hardwoods are often controlled prior to longleaf regeneration efforts (Provencher et al. 2001). However, this practice of hardwood reduction has seen mixed results. While there is some evidence this method works in the more mesic parts of the longleaf range (Harrington \& Edwards 1999), anecdotal evidence suggests that hardwood reduction has been less effective at reducing competition for resources on more xeric sites, such as the North Carolina Sandhills. In fact, recent evidence suggests that certain midstory hardwoods may actually facilitate the survival of newly established seedlings on xeric sites (Loudermilk et al. 2016). There has been some research comparing the biology of longleaf on xeric and mesic sites (Espeleta \& Donovan 2002, Addington et al. 2006), but the relationship of competition and facilitation between longleaf pine seedlings and midstory hardwoods on xeric sites is an area of research deserving of more attention.

\subsection{Considerations for Xeric Sites}

Regenerating longleaf on xeric sites presents a different set of challenges in contrast to more mesic sites. Light is generally the most important resource in longleaf forests (Jose et al. 2006), but xeric conditions can give preference to plant communities 
that are adapted to moisture or nutrient stress rather than low-light conditions. Moisture stress may limit mature leaf area in other conifers (Grier \& Running 1977), and therefore can lead to reduced understory competition for light. Acknowledging the shift from light limitation to moisture limitation is critical when considering stand dynamics on xeric sites, as plant responses can differ drastically between xeric and mesic sites (Espeleta \& Donovan 2002, Addington et al. 2006). While xeric broadly defines dry soil conditions, differences in soil moisture release curves can vary greatly. For example, deep sandy soils can be considered xeric due to rapid permeability and high drainage. However, clay soils can also be considered xeric due to very slow permeability and high runoff.

The moisture availability of a site exerts a strong influence on plant community structure, but nutrient availability can be an important consideration for xeric sites as well. In temperate forest ecosystems, nitrogen is often the most limiting nutrient and may be influenced by various site characteristics (Vitousek \& Howarth 1991). This may be due to the fact that in deep, sandy soils, potential net nitrogen mineralization rates are much lower than for shallower sandy soils (West et al. 2004), as well as increased leaching due to high runoff. However, Wilson et al. (1999) found greater nitrogen availability on xeric sites compared to mesic and wetland sites. They hypothesized that this may be due to greater quality nutrient inputs from hardwood litter and/or warmer soils leading to accelerated decomposition under suitable soil moisture. Therefore, microsite variability may be an important consideration for nutrient availability on xeric sites.

It logically follows that stress-reducing traits are selected for in plants in xeric environments (Aerts 1999). Specifically, the xeric Carolina Sandhills generally have poor 
nutrient retention (Espeleta \& Donovan 2002). The nutrient and moisture limitation of xeric sites can lead to severe stress and reduced longleaf seedling growth (Jose et al. 2003). While longleaf is generally well-adapted to xeric conditions, moisture and nutrient stress could prolong the grass stage, which in turn could prohibit newly established seedlings from competing for light availability with established vegetation.

\subsection{Competition and Facilitation}

Plant interactions can greatly influence regeneration dynamics. The two most studied examples of these interactions are competition (a negative effect caused by the presence of neighboring plants) and facilitation (a positive effect of a neighboring plant). Examples of direct and indirect competitive interactions include reducing resource availability (Parish \& Bazzaz 1982), occupying physical growing space (Wilson 1988), and allelopathy (Li et al. 2010). Conversely, examples of facilitation can be reduction of plant stress via increased moisture availability through shading and hydraulic lift (Holmgren et al. 1997) and reduced competition through allelopathy (Conway et al. 2002). Facilitation can be seen in a wide range of ecosystems such as deserts (Franco and Nobel 1989), Great Lakes sand dunes (Kellman and Kading 1992), and montane bunchgrass communities in Montana (Greenlee and Callaway 1996). Whether the interaction between neighboring plants is facilitative or competitive depends on the relative stress of the site and the plants' ability to mitigate stress. According to the stressgradient hypothesis, facilitative processes are more common on harsh sites, where abiotic conditions necessitate stress tolerance (Maestre et al. 2009). Prior to the formalization of the stress-gradient hypothesis, this relationship between competition and facilitation had been acknowledged (Callaway \& Walker 1997, Holmgren et al. 1997). Additionally, this 
hypothesis has been revisited to include facilitative interactions that do not fall along the typical stress gradient (Holmgren \& Scheffer 2010). However, little work has been done on the facilitative interactions that may be taking place in longleaf ecosystems, and how this relationship functions, specifically during the grass stage of longleaf pine.

\subsection{Competition and Facilitation in the Longleaf Ecosystem}

Managing moisture stress is critical for plants' survival on xeric sites. Mature longleaf is drought tolerant due to its deep taproot and extensive root system (Burns \& Honkala 1990), but various factors are critical to consider regarding the moisture stress of young seedlings ( $<2$ years) because they are more susceptible to drought induced mortality (Rodriguez-Trejo et al. 2003). One mechanism of facilitation is the utilization of nurse plants, which is a plant that offers a more favorable habitat for plant growth beneath its canopy than the surrounding environment (Ren et al. 2008). Alleviation of moisture stress can be seen with adult longleaf pine and turkey oak (Quercus laevis Walt.) acting as nurse plants for longleaf seedlings (Pecot et al. 2007, Loudermilk et al. 2016). The facilitative mechanisms of interest for this moisture stress alleviation are shade and hydraulic lift from the hardwood midstory, in particular, turkey oak. However, mature longleaf pine have also been shown to exhibit hydraulic lift (Espeleta et al. 2004).These facilitative mechanisms have not been studied directly, but it is important to consider how these mechanisms may function at different forest canopy levels.

A mature longleaf overstory can greatly impact moisture dynamics with respect to longleaf seedlings. First, mature longleaf may facilitate seedlings by providing shade, potentially reducing seedling transpiration and soil moisture evaporation in the summer. However, this shade is present year-round and may not be beneficial in the spring and 
fall. Second, overstory longleaf may also facilitate seedling survival through increasing moisture availability. Mature longleaf have been shown to exhibit hydraulic lift (Espeleta et al. 2004), which moves water from deep in the soil profile to the upper horizons. Hydraulic lift has not been shown to directly facilitate longleaf seedlings, but this may be a potential mechanism of facilitation as this scenario has been shown in other systems (Caldwell \& Richards 1989). Additionally, longleaf needles may provide a positive or negative effect on soil moisture by increasing fire intensity and soil moisture evaporation (Thaxton \& Platt 2006), or reducing soil moisture evaporation by insulating the soil (Ginter et al. 1979). Another mechanism of seedling facilitation to consider is the role of mycorrhizae. While longleaf pine indeed form mycorrhizal associations (Sims et al. 2007), little research has been done on the facilitative effects of these mycorrhizae. Mature longleaf can also compete with seedlings for resources depending on abiotic stress, overstory density, and distance to seedlings (Brockway \& Outcalt 1998).

Midstory hardwoods may also mitigate harsh environmental conditions at the forest floor. However, these effects may vary seasonally due to phenology. This temporal dynamic is critical to explore to understand how longleaf seedling moisture stress changes throughout the year. Similar to mature longleaf, turkey oak has also been shown to exhibit hydraulic lift (Espeleta et al. 2004), but this has only been hypothesized as a mechanism of facilitation (Loudermilk et al. 2016). Turkey oak litter has also been shown to increase fire intensity (Hiers et al. 2014, Kane et al. 2008, Varner et al. 2016), and potentially soil moisture evaporation. While hardwood saplings in the midstory may compete with longleaf seedlings for resources, a frequent fire regime periodically releases seedlings from hardwood competition until the hardwoods resprout (Cavender-Bares et 
al. 2004). Understory light availability has been shown to affect brown spot needle blight infection (Kais 1975), and assessing brown spot infection in relation to hardwood midstory presence is critical for defining the facilitative relationship.

A critical factor to consider while examining these relationships is that these interactions can become competitive rather than facilitative under certain conditions. As seen in Callaway and Walker (1997), the facilitative strength of a nurse plant decreases as abiotic stress decreases. Additionally, according to the stress gradient hypothesis, the impact of shade and hydraulic lift may be lessened if abiotic stress is minimal. Therefore, while these facilitative mechanisms may play a significant role in longleaf seedling survival, their effects may vary significantly depending on abiotic conditions and life history stages.

While it has been established that there is some facilitative interaction between pyrophytic oaks and longleaf pine seedlings, the balance between competition and facilitation has not yet been investigated. Identifying not only the mechanisms of facilitation but also the dynamics of competition and facilitation are critical to managing longleaf pine forests for more successful regeneration. 


\section{CHAPTER III}

\section{INTRODUCTION}

The longleaf pine ecosystem is recognized as one of the most unique and dynamic ecosystems in North America (Van Lear et al. 2005). Among its many desirable characteristics, the longleaf ecosystem provides habitat for a diverse array of flora and fauna (Noss et al. 1995). It has been estimated that the longleaf ecosystem is capable of supporting between 150-300 grass and forb species per hectare (Means 1996). The availability of longleaf habitat is also critically important for an estimated 96 species that are endemic to the longleaf ecosystem (Walker 1995). In addition to its contributions to biodiversity and wildlife habitat, the longleaf ecosystem has served as a valuable timber resource since European settlement (Frost 1993).

Unfortunately, the future of the longleaf ecosystem is currently threatened (Noss et al. 1995). Once dominant over 38 million ha across the southeastern Coastal Plain, the longleaf ecosystem has been reduced to less than two percent of its historical range (Outcalt \& Sheffield 1996). This reduction began with exploitative harvesting from the timber and naval stores industries in the 1800 's, limiting longleaf seed source availability (Frost 1993). Regeneration of seedlings was subsequently suppressed due to implementation of fire suppression policies (Wade \& Lundsford 1989), browsing from feral hogs (Mayer et al. 2000), and conversion to faster growing timber species such as loblolly pine (Frost 1993). 
Acknowledgement of the importance of the longleaf ecosystem has increased over the since the late 1970's (U.S. Fish and Wildlife Service 2003, first version 1979). Several silvicultural advancements have aided restoration efforts, including the relaxation of fire suppression policies. The development of containerized seedlings (Barnett \& Brissette 1986) and site preparation treatments have aided in increasing seedling survival during regeneration efforts (Harrington et al. 1998). Recognition of the importance of fire in the longleaf ecosystem has also improved over time, allowing for a greater awareness of the problematic legacy of fire suppression (Van Lear et al. 2005). Despite these improvements, longleaf regeneration efforts still face many challenges (Brockway et al. 2006, Gagnon et al. 2004). These challenges typically occur during the longleaf seedling stage.

Longleaf seedlings exhibit a unique life stage called the grass stage for two to eight years depending on light, moisture, and nutrient availability (Burns \& Honkala 1990). Seedlings in the grass stage resemble clumps of grass, as only their long, dense needles are exposed aboveground. Grass stage longleaf seedlings focus on belowground development until they reach a root collar diameter of $2.5 \mathrm{~cm}$, after which they are highly likely to initiate height growth (Burns \& Honkala 1990). The grass stage is critically important to the survival and regeneration of longleaf pine in frequently burned ecosystems (Burns \& Honkala 1990, Keeley \& Zedler 1998). Unlike species less adapted to fire, such as loblolly and slash pine (Burns \& Honkala 1990), which lack the grass stage, longleaf's dense, moisture containing needles help protect the terminal bud from heat, improving the odds of survival (Bruce 1951). In the aftermath of fire, longleaf seedlings gain greater access to resources as a result of the mortality of other less fire- 
adapted species (Brockway \& Lewis 1997). Competition reduction through fire is a critical component of the longleaf ecosystem, as grass stage seedlings will not initiate height growth without sufficient light, and require high light environments for survival (Burns and Honkala 1990, Gilliam \& Platt 1999). Therefore, the absence of fire, resulting from decades of fire suppression, was highly detrimental to longleaf regeneration as the grass stage strategy became a competitive liability rather than an advantage.

Some of the more consistent issues for longleaf regeneration since the fire suppression era have been increased competition from mature overstory pines (Brockway \& Outcalt 1998, Outcalt 2000), midstory hardwoods (Van Lear et al. 2005), and the fungal pathogen brown spot needle blight (Boyer 1975). Increased overstory pine density, resulting from greater regeneration success in the fire suppression era and the establishment of fire sensitive pines (Outcalt \& Sheffield 1996), has been shown to have negative impacts on longleaf seedling survival and growth through competition for resources (Grace \& Platt 1995, Brockway \& Outcalt 1998). Midstory hardwoods have also been shown to inhibit longleaf regeneration by limiting light availability, as they quickly grow beyond the height of longleaf seedlings in the grass stage, forming a dense, light-limiting canopy (Jose et al. 2006, Pecot et al. 2007). Midstory hardwoods also compete strongly with longleaf seedlings for belowground resources (Brockway \& Outcalt 2000, Provencher et al. 2001). The addition of slow-decomposing hardwood litter (Conn \& Dighton 2000) can also inhibit longleaf germination, which requires bare mineral soil (Facelli \& Pickett 1991). Another challenge to longleaf regeneration is brown spot needle blight. Brown spot is a native fungal pathogen that infects needles and can delay growth and cause mortality, most commonly in the grass stage of development 
(Phelps et al. 1978). Management that extends the length of the grass stage has the potential to increase brown spot mortality (Boyer 1975). However, studies have also shown greater infection at higher light levels due to stomatal openings providing an entrance into longleaf seedling needles (Kais 1975), bringing traditional strategies for management (such as utilizing clearcut or seed-tree methods) into question.

In order to overcome these regeneration challenges, current management practices manipulate conditions of the overstory, midstory, and understory. Longleaf is typically regenerated artificially by clearcutting and planting containerized seedlings. For natural regeneration, seed-tree (residual basal area 20-25 trees/ha) (Mitchell et al. 2006) or modified shelterwood systems (residual basal area of $13.8-16.1 \mathrm{~m}^{2} / \mathrm{ha}$ ) (Walker 1995) are utilized to increase seed tree vigor and provide sufficient seed sources. Both artificial and natural regeneration practices seek to provide high-light environments for longleaf seedling development, and may utilize prescribed fire as a site preparation technique to reduce competition and expose bare mineral soil for seedling germination (Facelli \& Pickett 1991). Midstory hardwoods are often controlled prior to longleaf regeneration efforts through herbicide, fire, or mechanical means to reduce competition for resources with grass stage seedlings (Provencher et al. 2001). Low-intensity, prescribed fire and herbicides can be utilized to further reduce herbaceous competition (Provencher et al. 2001). Following seedling establishment, prescribed fire can also be used to control infection rates of BSNB (Phelps et al. 1978). Through these current management practices, historical stand conditions are maintained by emulating natural disturbance.

However, in some situations, longleaf regeneration must be accomplished within the structure of additional natural resource objectives, preventing the use of established 
silvicultural techniques. For example, managing mature longleaf stands for red-cockaded woodpecker habitat has become a common natural resource objective (Hiers et al. 2014). $\mathrm{RCW}$ is an endangered bird found in the longleaf ecosystem that prefers large diameter trees for cavities (Rudolph \& Conner 1991) and large longleaf forests for foraging (Henry 1989). When managing for RCW, overstory trees are maintained at a density of 12 to 18 $\mathrm{m}^{2} /$ ha to provide sufficient cavity trees and an open canopy that is preferred by RCW (U.S. Fish and Wildlife Service 2003). It is also strongly recommended to not allow the midstory to exceed $2 \mathrm{~m}$ in height, whether through prescribed fire, herbicide, or mechanical control, to maintain the open canopy preferred by RCW (Costa 1992).

While management for RCW habitat has some common characteristics with traditional longleaf regeneration practices, some potentially important differences do exist, bringing the compatibility of these management objectives into question. For instance, maintaining a lower overstory density than current $\mathrm{RCW}$ practices may increase light availability enough to bring longleaf seedlings out of the grass stage (Mitchell et al. 2006), but also may put seedlings at greater risk to BSNB infection due to increased light levels (Kais 1975). Conversely, higher overstory density may impede the ability of longleaf seedlings to exit the grass stage, increasing the risk of BSNB mortality (Grace \& Platt 1995). Proximity to mature pines have been shown to inhibit longleaf seedling growth and survival through intense belowground competition and increased fire intensity from pine litter (Brockway \& Outcalt 1998). It is necessary to ensure sufficient cavity trees for RCW habitat (Rudolph \& Conner 1991), but the impact of current guidelines on longleaf regeneration warrants further investigation to ensure the sustainability of the longleaf ecosystem. 
Another potentially problematic feature of RCW management for longleaf regeneration on xeric sites is the practice of controlling midstory hardwoods. Although this practice is consistent with traditional longleaf regeneration practices, a growing body of evidence suggests that midstory hardwoods may facilitate the survival of newly established seedlings on xeric sites (Wahlenburg 1946, Gaines 1950, Espeleta et al. 2004, Loudermilk et al. 2016). Regenerating longleaf pine on xeric sites presents a different type of challenge for management, due to the low moisture content and nutrient availability (Espeleta \& Donovan 2002). These conditions result in less productive ecosystems (Nowacki \& Abrams 2008). A potentially relevant theory explaining this phenomenon is the stress gradient hypothesis, which states that as abiotic stress increases in an ecosystem, so does the likelihood of facilitative interactions (Maestre et al. 2009). As such, the relationship between midstory hardwoods and grass stage longleaf seedlings so often characterized by studies conducted on more mesic sites as being competitive, may actually be facilitative on more xeric sites. Specifically, pyrophytic (fire-tolerating) oaks (such as turkey oak) are strong competitors for moisture (Abrams 1990), but may provide facilitative effects on xeric sites. These include maintaining the fire regime with similar litter burn characteristics (Varner et al. 2015), providing shade to longleaf seedlings (Allen 1954), and hydraulic redistribution of water to the upper soil profile (Espeleta et al. 2004). Placing the interaction between longleaf seedlings and midstory hardwoods in the context of a variable overstory density on xeric sites is necessary for understanding the conditions of a potential facilitative relationship, and how long this relationship may last. 
The mechanisms of how these midstory hardwoods may be facilitating longleaf regeneration have not been thoroughly investigated. It is undisputed that longleaf seedlings require light to regenerate (Burns \& Honkala 1990), however under current overstory guidelines for RCW, many longleaf forests are not light limited (Costa 1992). While the importance of light and moisture have been recognized in the literature (Jose et al. 2003), the mechanisms of these factors have not been evaluated under a hardwood midstory. It is also unknown how the presence of midstory hardwoods affects the infection rates of BSNB. Additionally, the interaction of the hardwood midstory and current overstory management guidelines on longleaf seedling regeneration is not well understood. Therefore, it is necessary to understand (1) how managing for RCW habitat overstory density affects longleaf regeneration; (2) how the presence or absence of midstory hardwoods affects longleaf regeneration; (3) how long the facilitative relationship between midstory hardwoods and longleaf seedlings may remain in effect; and (4) what mechanisms are relevant to this facilitative interaction. Clarifying the mechanisms and temporal aspects of the relationship between overstory, midstory, and understory is of great importance for the restoration of the longleaf ecosystem, as current RCW management efforts that remove midstory hardwoods prior to seedling establishment may be inadvertently contributing to regeneration failures. 


\section{CHAPTER IV}

\section{METHODS}

\subsection{Site Description}

My experiment was conducted in the Sandhills Ecoregion of North Carolina ( $35^{\circ}$ 3' $34.6932^{\prime}$ N, $79^{\circ} 22^{\prime} 22.0872$ " W) on a site, named the McCain Tract, managed by the North Carolina Department of Agriculture and Consumer Services. Average monthly temperatures (1981-2010) range from highs of $11.5^{\circ} \mathrm{C}(\mathrm{Jan})$ to $32.4{ }^{\circ} \mathrm{C}(\mathrm{Jul})$ to lows of $0.8^{\circ} \mathrm{C}$ (Jan) to $21.3{ }^{\circ} \mathrm{C}$ (Jul) (Fayetteville, NC; NCEI, NOAA). Average monthly rainfall (1981-2010) ranges from $75 \mathrm{~mm}$ (Nov) to $141 \mathrm{~mm}$ (Aug) (Fayetteville, NC; NCEI, NOAA), with an average annual total precipitation (1940-2017) of $1084 \mathrm{~mm}$ (Charlotte, NC; NCEI, NOAA). All experimental plots were established within a mature longleaf pine stand growing on the Candor soil series (Soil Series Staff, NRCS 2008). The relevant characteristics of this series are that it has rapid permeability with no flooding frequency, and is sandy throughout the entire soil profile while somewhat clayey and loamy at the deepest soil horizons (1.5-2 m). Longleaf pine is the dominant overstory species at the site, with basal areas ranging from 2 to $41 \mathrm{~m}^{2} /$ ha (Table 4.1 ). The midstory $(6,228 \mathrm{stems} / \mathrm{ha})$ is dominated by turkey oak $(82.3 \%)$ with admixtures of blackgum (Nysssa sylvatica Marsh.; 9.1\%) and sassafras (Sassafras albidium (Nutt.) Nees; 6.6\%). Across the site, hardwood heights range from $0.1 \mathrm{~m}-6.7 \mathrm{~m}$, with an average height of $1.2 \mathrm{~m}$ (Table 4.1). The herbaceous layer is dominated by wiregrass (Aristida stricta 
Michx.) (Table 4.1). The site is primarily managed to maintain red-cockaded woodpecker habitat with a secondary objective being longleaf pine regeneration. To accomplish both objectives, the stand is treated with a dormant season (December - February), lowintensity prescribed fire on a 3-year return interval.

\subsection{Experimental Design}

My experiment was established as a randomized complete block design. In February of 2016, 15 experimental blocks ( $0.10 \mathrm{ha})$ were established across a gradient of longleaf pine overstory density $\left(2-41 \mathrm{~m}^{2} / \mathrm{ha}\right)$. Nine plots $(0.002 \mathrm{ha})$ were nested within each block (Figure 4.2). Overstory density was determined at the plot level with a 10factor prism, and plots were then placed into one of three groups of overstory density based on RCW management guidelines (Costa 1992): $<12 \mathrm{~m}^{2} / \mathrm{ha}$ (low), $12-18 \mathrm{~m}^{2} / \mathrm{ha}$ (prime), $>18 \mathrm{~m}^{2} / \mathrm{ha}$ (high). Each plot was planted with 16 containerized, one-year-old longleaf pine seedlings spaced one meter apart. Midstory hardwoods were chemically controlled by treating prior to planting (R0), treating after one year (R1), or left untreated (UN) for the entirety of the experiment (two years, $2016 \& 2017)$. Plot treatments consisted of cut stump treatment of midstory hardwoods in one third of the plots with Brushtox Brush Killer herbicide (61.6\% Triclopyr, Ragan and Massey, Inc., Gig Harbor, WA) mixed with methylated seed oil in a ratio of 1:9 (one part oil to nine parts herbicide) each year in May with the goal of eliminating the hardwood midstory. For any hardwood sprouts that survived the cut stump treatment, the foliage was sprayed with the same herbicide the following summer. Treatments were assigned to plots non-randomly based on initial hardwood density (i.e. plots with lowest oak densities were selected as (R0) in order to ensure adequate and less variable midstory hardwood stocking in the remaining 
plots intended to examine their potential impact). To eliminate potential edge effects, each plot was separated by at least one buffer plot that received the same treatment as its nearest planted plot (Figure 4.2).

Table 4.1 Site Characteristics by Block

\begin{tabular}{ccccccc} 
Average & $\begin{array}{c}\text { Average } \\
\text { Overstory } \\
\text { Clover } \\
\text { of } \\
\text { Basal Area } \\
\left(\mathrm{m}^{2} / \text { ha }\right)\end{array}$ & $\begin{array}{c}\text { Average } \\
\text { Wiregrass }\end{array}$ & $\begin{array}{c}\text { Average } \% \\
\text { of Forbs } \\
\text { Cover of } \\
\text { Bare Soil }\end{array}$ & $\begin{array}{c}\text { Average } \% \\
\text { Soil } \\
\text { Moisture } \\
\text { Jun-Aug } \\
(15 \mathrm{~cm})\end{array}$ & $\begin{array}{c}\text { Average } \% \\
\text { of Max } \\
\text { Light Above } \\
\text { Midstory }\end{array}$ \\
\hline 1 & $18.1 \pm 8.2$ & $28 \pm 15$ & $9 \pm 8$ & $62 \pm 13$ & nd & $65 \pm 26$ \\
2 & $13.3 \pm 7.7$ & $22 \pm 16$ & $6 \pm 2$ & $72 \pm 18$ & nd & $62 \pm 36$ \\
3 & $12.5 \pm 4.5$ & $40 \pm 9$ & $12 \pm 9$ & $46 \pm 14$ & $35 \pm 6$ & $53 \pm 28$ \\
4 & $6.9 \pm 2.8$ & $42 \pm 16$ & $8 \pm 4$ & $44 \pm 18$ & nd & $64 \pm 29$ \\
5 & $8.2 \pm 5.4$ & $36 \pm 10$ & $16 \pm 6$ & $48 \pm 12$ & $38 \pm 5$ & $61 \pm 35$ \\
6 & $6.6 \pm 4.7$ & $43 \pm 18$ & $8 \pm 4$ & $46 \pm 21$ & $34 \pm 3$ & $62 \pm 34$ \\
7 & $12.2 \pm 4.6$ & $29 \pm 17$ & $16 \pm 16$ & $55 \pm 21$ & nd & $59 \pm 33$ \\
8 & $24.0 \pm 9.3$ & $28 \pm 9$ & $5 \pm 3$ & $67 \pm 9$ & $38 \pm 5$ & $68 \pm 27$ \\
9 & $10.2 \pm 5.2$ & $26 \pm 10$ & $5 \pm 5$ & $63 \pm 16$ & $38 \pm 4$ & $80 \pm 30$ \\
10 & $18.9 \pm 5.8$ & $29 \pm 13$ & $1 \pm 2$ & $62 \pm 12$ & $34 \pm 6$ & $56 \pm 38$ \\
11 & $17.1 \pm 7.5$ & $31 \pm 13$ & $2 \pm 4$ & $60 \pm 11$ & nd & $57 \pm 37$ \\
12 & $22.5 \pm 9.9$ & $33 \pm 10$ & $1 \pm 2$ & $60 \pm 13$ & nd & $40 \pm 26$ \\
13 & $16.1 \pm 7.4$ & $31 \pm 15$ & $1 \pm 2$ & $63 \pm 13$ & nd & $57 \pm 36$ \\
14 & $11.2 \pm 7.6$ & $40 \pm 13$ & $3 \pm 3$ & $49 \pm 16$ & nd & $62 \pm 40$ \\
15 & $15.8 \pm 7.1$ & $30 \pm 15$ & $6 \pm 3$ & $57 \pm 12$ & $38 \pm 6$ & $59 \pm 31$ \\
\hline
\end{tabular}

Physical and biological characteristics of the site by block plus/minus one standard deviation. Block characteristics include average overstory basal area and average percent cover of: wiregrass, forbs, bare mineral soil, summer (Jun - Aug) soil moisture at a depth of $15 \mathrm{~cm}$, and max light above the hardwood midstory (\%). Only seven blocks (representative of the range of overstory density) were selected for soil moisture measurement due to sampling limitations (nd indicating no data). 


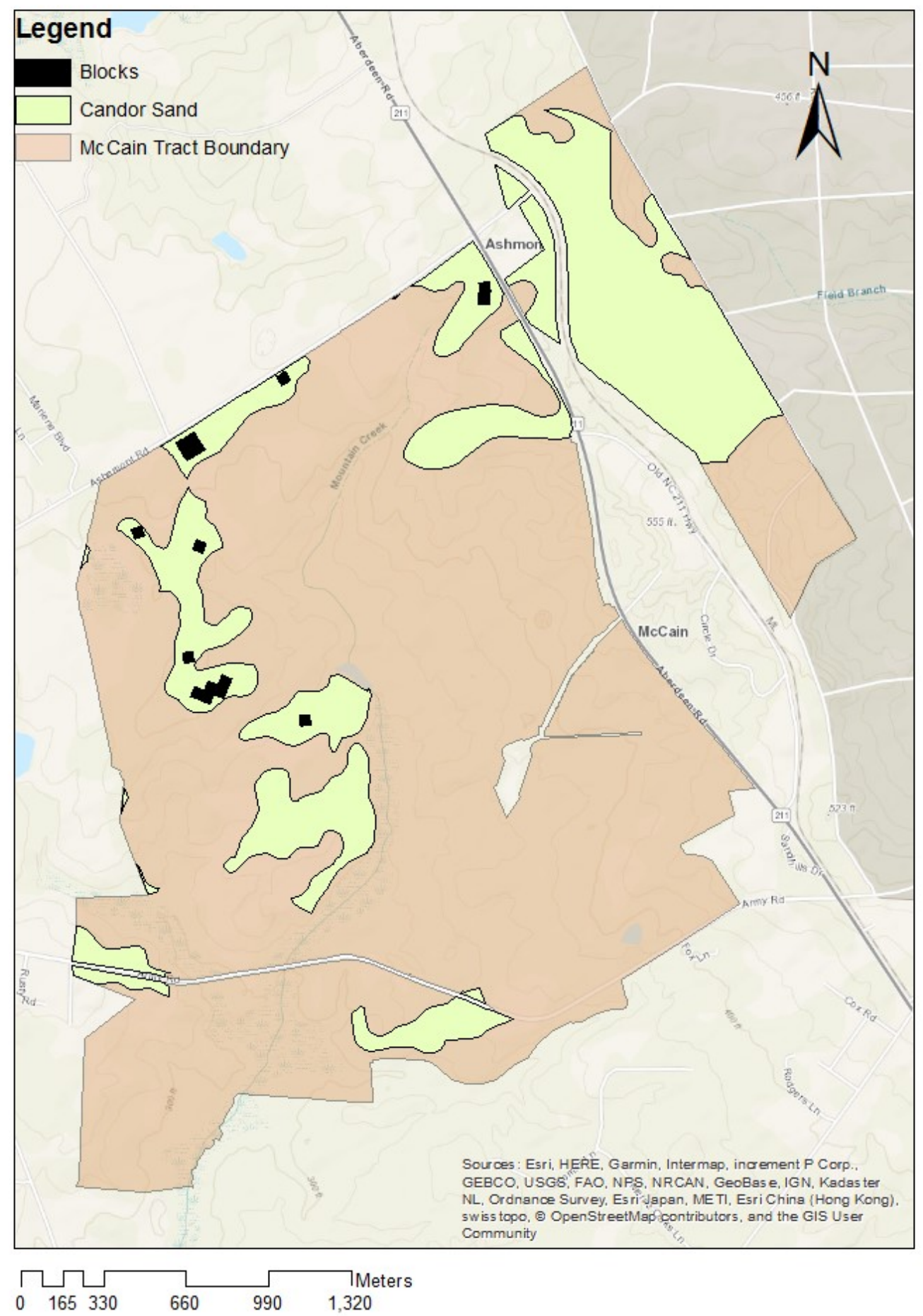

Figure 4.1 Site Map

Site map of the McCain tract with blocks (black) on the Candor Sand soil series (yellow) in the North Carolina sandhills. 


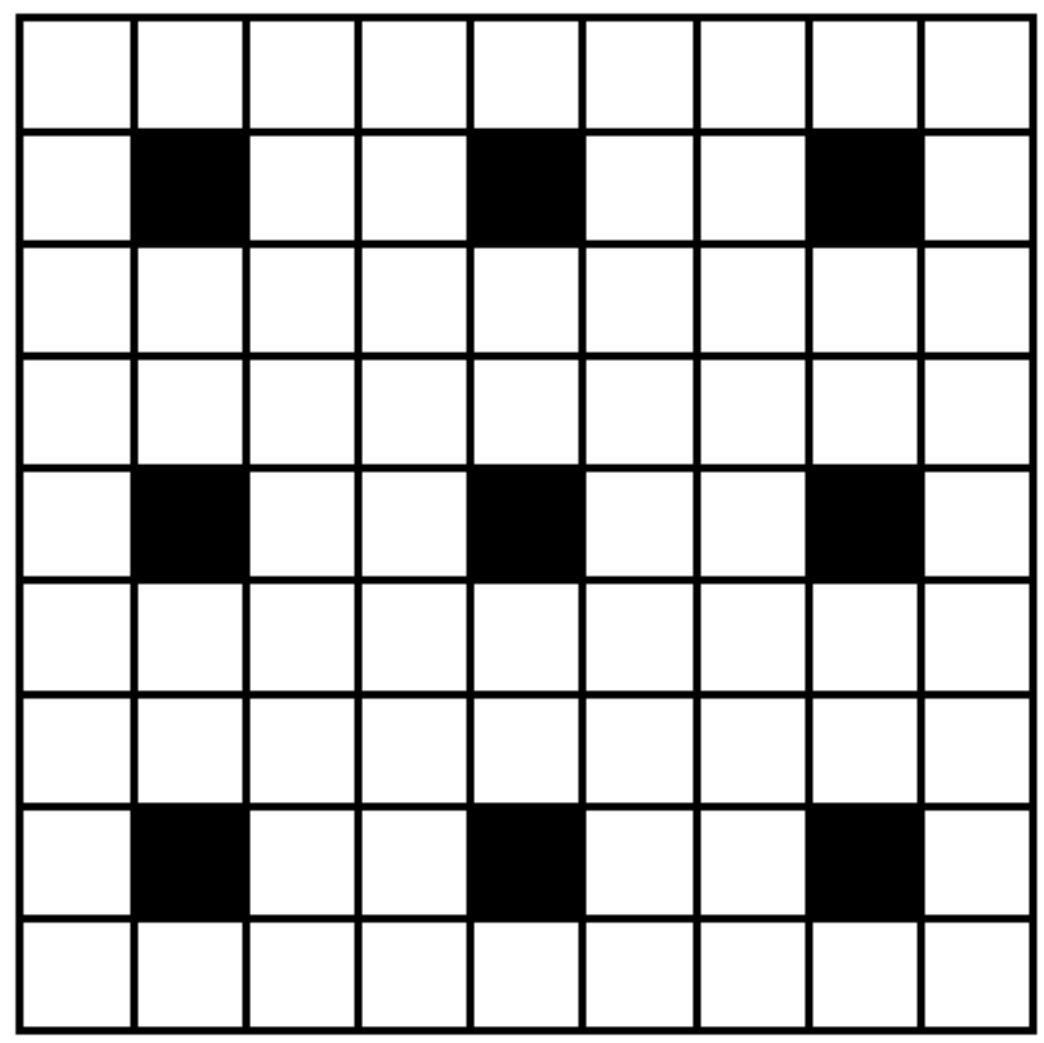

Figure 4.2 Block Diagram

Block ( 0.10 ha) diagram with nested measurement plots (black; 0.002 ha each) and treatment plots ( 8 white sections around each measurement plot; 0.002 ha each) in the North Carolina sandhills.

\subsection{Sampling Design}

Seedling survival and growth were measured in October 2017 at the end of the second growing season. Seedling survival was recorded for every seedling and averaged at the plot level. Three metrics were used to quantify seedling development: root collar diameter (mm), number of fascicles (total per seedling), and aboveground dry biomass (grams). Each metric was collected from a random subsample of four seedlings per plot. Root collar diameter (RCD) was measured with digital calipers at the ground line and 
was chosen because it is traditionally used as the metric for longleaf seedling growth and has been shown to relate to taproot length (Pessin 1938). Fascicle counts were collected as a potential early indicator of seedling vigor as, given the low productivity potential of xeric sites and the short duration of this study, it was uncertain that seedlings would begin allocating resources to RCD growth by the final measurement or that differences among treatments would be apparent by the end of the study. In addition, I was interested in examining how well aboveground biomass correlated to RCD and fascicle counts. A subsample of four randomly selected seedlings per plot were destructively sampled for dry aboveground biomass measurements to quantify total aboveground growth. These seedlings were cut at the ground-line, stored in Zip-loc bags in a cooler with ice packs, transported to Mississippi State University, dried in an oven for 48 hours at $70^{\circ} \mathrm{C}$, and subsequently weighed.

A sub-sample of two randomly selected seedlings from each midstory treatment from each block were assessed for predawn moisture stress (MPa) in March and July of the second growing season (2017) with a Scholander-type pressure chamber (Plant Water Status Console 3000 series, Soil Moisture Equipment Corp. Santa Barbara, CA). Moisture stress was measured to develop a greater mechanistic understanding of how midstory hardwoods and overstory density influence seedling moisture stress.

Additionally, the photosynthetic rate $\left(\mu \mathrm{mol} \mathrm{CO} \mathrm{Cm}^{-2}\right.$ leaf area s $\left.\mathrm{s}^{-1}\right)$ and transpiration rate ( $m m o l ~ \mathrm{H}_{2} \mathrm{O} \mathrm{m}^{-2}$ leaf area $\mathrm{s}^{-1}$ ) of two randomly selected seedlings per unique midstory treatment (treatment X block) were measured in March and July of the second growing season (2017) between approximately 10:00 a.m. and 12:00 p.m. using a Li-Cor 6400 Portable Photosynthesis System (Lincoln, NE) to assess differences in photosynthetic 
capacity and water use. These dates were selected based on the phenologies of longleaf pine and turkey oak (Fox et al. 1997): March measurements quantified photosynthetic activity of longleaf seedling prior to turkey oak leaf out, and July measurements demonstrate the effect of turkey oak on longleaf photosynthetic activity under stressful growing conditions. In plots with no hardwood midstory, the comparison between March and July measurements may show additional effects on seedling physiology. Li-Cor 6400 parameters were as follows: $\mathrm{CO}_{2}$ reference was set at $400 \mathrm{ppm}$, photosynthetically active radiation (PAR) was set at $500 \mathrm{ppm}$, and relative humidity was controlled to approximately $40 \%$. Additionally, Li-Cor measurements were scaled to needle area, as needles did not fill the Li-Cor measurement chamber. Brown spot infection was recorded at the seedling level as a binary presence or absence. The presence/absence of BSNB infection of all seedlings was assessed in October 2017 to determine the effect of overstory density and a hardwood midstory on the infection rates of BSNB.

In order to determine whether moisture stress influences longleaf seedling performance, soil moisture and temperature were measured once per month from March (before oak bud break) to October (after oak leaf-off) of 2017. Soil moisture and temperature were measured between 11:00 a.m. and 1:00 p.m. with an Aquaterr TEMP350 Digital Soil Moisture and Temperature Meter (Aquaterr, Costa Mesa, CA) at two depths per location: 0-15 $\mathrm{cm}$ and 0-30 $\mathrm{cm}$. Soil moisture and temperature were measured in each midstory treatment at seven blocks representative of the range overstory density (a total of 21 locations).

During the July field measurements, the longleaf seedling light environment was quantified by recording a light reading with a Li-Cor line quantum sensor (LI-COR 
Biosciences, Lincoln, NE) at seedling level (approximately $0.2 \mathrm{~m}$ ) and at a height of two meters (above the hardwood midstory) in the center of each plot. Measurements were taken in a window of two hours before and after solar noon to reduce variability from light angle, and were done on a day with clear skies.

Understory vegetation and bare cover were assessed in July 2017 by visually estimating percent of ground cover, by cover type, to the nearest $5 \%$ over each plot. The categories for this survey were as follows: shrub, grass, forb, and bare soil. Midstory species stem density, height, crown length, and crown width were measured in late summer of 2016 to determine midstory density at the plot level.

\subsection{Statistical Analysis}

Linear mixed models were utilized to explore the impacts of overstory density, midstory hardwood presence, the interaction between overstory density and midstory hardwoods, and Block on longleaf seedling growth, survival, and BSNB infection (Table 5.1). Overstory density and midstory treatments were considered fixed effects, while Block was considered a random effect. The response variables of survival, biomass, and BSNB infection were averaged at the plot level $(\mathrm{n}=135)$. Mixed model selection was accomplished through backwards selection, where all effects were placed in the model, and subsequently removed when results of Type 3 tests were non-significant. Significant effects were then further explored with Tukey-Kramer multiple comparison tests, to identify significant differences between midstory treatments or overstory groupings. The influence of Block was evaluated for significance as a random effect with a $t$-test within a variance components covariance structure. Use of the variance components covariance 
structure was required for convergence. All tests were evaluated at the $\alpha=0.05$ level. Residuals were evaluated for all models to ensure assumptions of normality, equal variance, and independence were not violated.

To further develop a mechanistic understanding of how overstory density and midstory hardwoods influence longleaf seedling growth and survival, I explored a series of correlative relationships. Specifically, I was interested in how overstory density and midstory hardwoods influenced light and moisture availability, and how longleaf seedlings responded to variations in availability of moisture and light. Pearson correlation analyses were used in all evaluations. To assess moisture dynamics, I first evaluated the effect of overstory density on soil moisture availability. Midstory treatments were evaluated regarding seedling predawn moisture stress and soil moisture availability. I then compared soil moisture availability to seedling predawn moisture stress and transpiration rate. Finally, I assessed both seedling predawn moisture stress and transpiration rate as they relate to seedling survival and growth.

To assess light dynamics, I first evaluated the effect of overstory density on light availability above and below the hardwood midstory, as well as seedling photosynthetic rates. Midstory hardwoods were also evaluated regarding their impact on light availability at the seedling level, soil temperature at 15 and $30 \mathrm{~cm}$ (to determine the effect of midstory shade on soil temperature), and seedling photosynthetic rate. I then compared light availability to average soil temperature at both depths, seedling photosynthetic rates, and BSNB infection rates.

Finally, I assessed seedling photosynthetic rates as they relate to seedling survival, growth, and BSNB infection rates. First, March and July measurements of 
seedling physiology were compared to assess the effect of a presence or absence of a hardwood midstory. To remove seasonal variability, only July measurements of seedling predawn moisture stress, transpiration rate, and photosynthetic rate were used in correlations. Correlations were also examined between the three growth metrics to determine the relationship between less common growth metrics (number of fascicles and aboveground biomass) and the traditional metric (root collar diameter). For significant correlations, linear regression analysis was performed to establish $\mathrm{R}^{2}$ values. All analyses were performed in SAS Enterprise Guide version 9.4 (SAS Institute Inc., Cary, North Carolina). 


\section{CHAPTER V}

\section{RESULTS}

\section{$5.1 \quad$ Longleaf Seedling Survival}

Seedling survival was best explained by a model containing the fixed effects of midstory treatment and overstory groupings, and the random effect of Block (Table 5.1). Seedling survival in overstory groupings differed significantly $(\mathrm{p}=0.0006$; Table 5.1), with seedlings growing beneath overstories of low density $(86 \pm 11 \%)$ having greater survival than those growing beneath overstories of high density $(73 \pm 16 \%)(p=0.0001$; Figure 5.1). Seedling survival in midstory treatments differed significantly $(p=0.0261$; Table 5.1), with seedlings growing beneath untreated midstories (UN) (84 $\pm 13 \%)$ having greater survival than seedlings whose hardwood midstory was removed after one year $(\mathrm{R} 1)(76 \pm 17 \%)(\mathrm{p}=0.0280 ;$ Figure 5.1$)$. The interaction of midstory hardwoods and overstory groupings did not significantly impact seedling survival. The random effect of Block also significantly influenced seedling survival $(\mathrm{p}=0.0083$; Table 5.1), with survival ranging from $61 \%$ to $94 \%$ among blocks. (Individual Block estimates are available in Table A.1.) 
Table 5.1 Type 3 Tests of Fixed Effects in Best Model for All Response Variables.

\begin{tabular}{|c|c|c|c|c|}
\hline Effect(s) & Effect Type & Survival & Biomass & BSNB \\
\hline Overstory Grouping & Fixed & $0.0006^{*}$ & $0.0007^{*}$ & $0.0014 *$ \\
\hline Midstory Treatment & Fixed & $0.0261 *$ & - & - \\
\hline Block & Random & $0.0083^{*}$ & $0.0026^{*}$ & $<0.0001 *$ \\
\hline
\end{tabular}



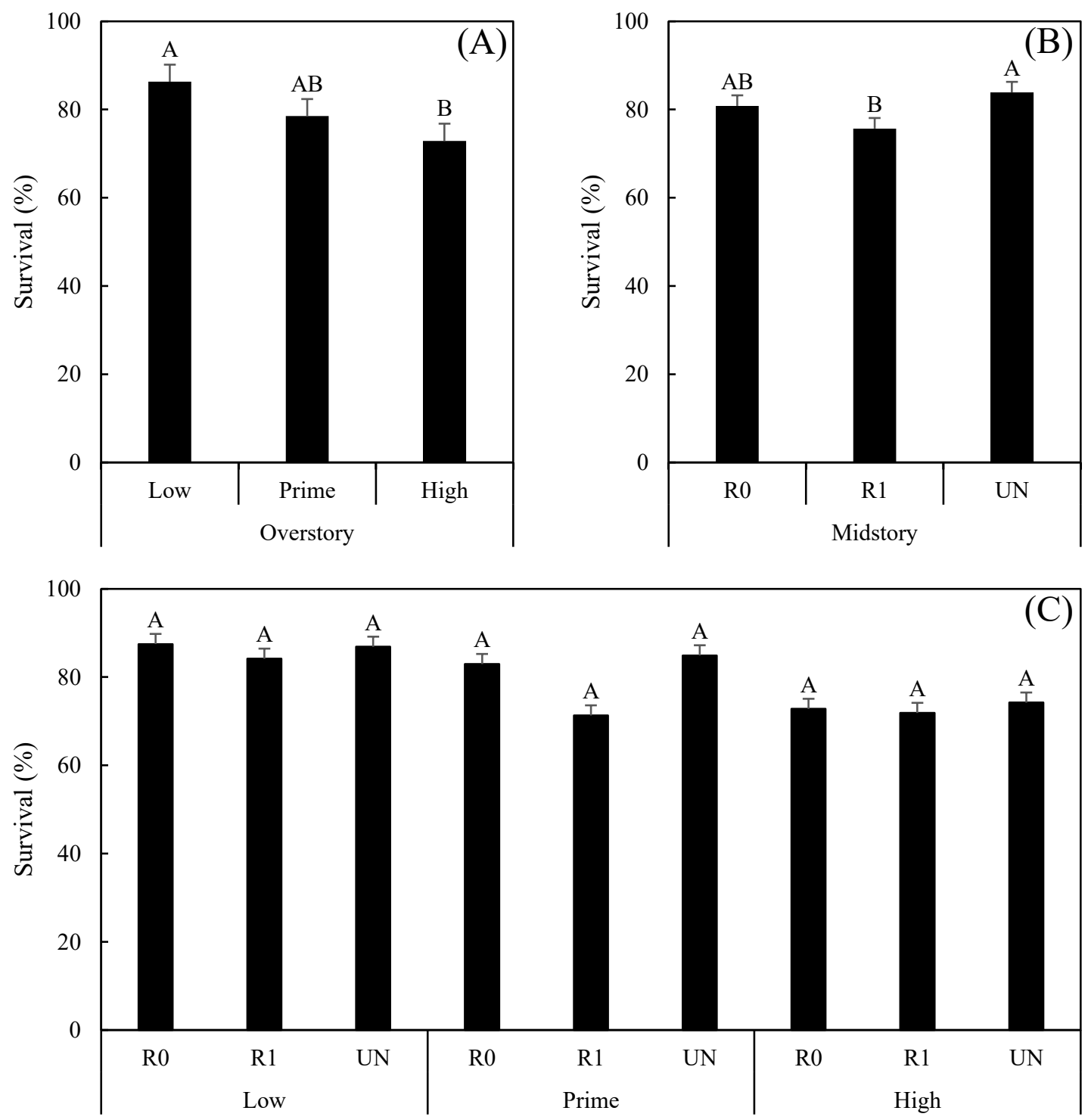

Figure 5.1 Survival Response to Fixed Effects.

Average survival (\%) of longleaf seedlings within (A) overstory groupings $\left(<12 \mathrm{~m}^{2} /\right.$ ha (low), $12-18 \mathrm{~m}^{2} /$ ha (prime), $>18 \mathrm{~m}^{2} /$ ha (high)), (B) midstory treatments (treating prior to planting (R0), treating after one year (R1), or left untreated (UN)), and (C) midstory treatments within overstory groupings. Error bars represent 1 Standard Error. Bars with differing letters denote a significant difference at the 0.05 level from a Tukey-Kramer MCP. 


\subsection{Longleaf Seedling Growth}

Seedling biomass provided the greatest resolution in growth compared to either root collar diameter or fascicle number, and is therefore used as the only growth metric for analysis. Pearson correlation analyses between the three growth metrics showed moderately positive, significant correlations between all three metrics (Table 5.2).

Seedling biomass was best explained by a model containing the fixed effect of overstory groupings, and the random effect of Block (Table 5.1). Seedling biomass in overstory groupings differed significantly $(\mathrm{p}=0.0007$; Table 5.1), with seedlings being significantly larger in the low density grouping $(10.9 \pm 1.2 \mathrm{~g}$ dry $\mathrm{wt})$ compared to either prime density $(10.3 \pm 1.0$ g dry wt; Figure 5.2$)$ or high density $(10.0 \pm 0.7 \mathrm{~g}$ dry wt; Figure 5.2). Among midstory treatments, (R0) had the greatest biomass (10.6 g dry wt). Midstory treatments and their interaction with overstory groupings did not significantly impact seedling biomass, and where therefore not included in the model (Table 5.1). In contrast, Block significantly influenced seedling growth $(\mathrm{p}=0.0026$; Table 5.1), with biomass ranging from 9.6 to $11.9 \mathrm{~g}$ dry wt among blocks. (Individual Block estimates are available in Table A.2.)

Table 5.2 Pearson Correlation Analyses for Growth Metrics.

\begin{tabular}{lrrr} 
Response Variable & $\begin{array}{r}\text { Average Biomass } \\
(\mathrm{g} \text { dry wt) }\end{array}$ & $\begin{array}{r}\text { Average \# } \\
\text { Fascicles }\end{array}$ & $\begin{array}{r}\text { Average } \\
\text { RCD }(\mathrm{mm})\end{array}$ \\
\hline Average Biomass (g dry wt) & 1 & 0.69947 & 0.64118 \\
& & $<.0001^{*}$ & $<.0001^{*}$ \\
Average \# Fascicles & 0.69947 & 1 & 0.47639 \\
& $<.0001^{*}$ & & $<.0001^{*}$ \\
Average RCD (mm) & 0.64118 & 0.47639 & 1 \\
\hline
\end{tabular}

Pearson correlation $\rho$ and $\mathrm{p}$ values for biomass ( $\mathrm{g}$ dry $\mathrm{wt}$ ), fascicles (number), and root collar diameter (RCD; mm). Significance at the 0.05 level denoted with *. 

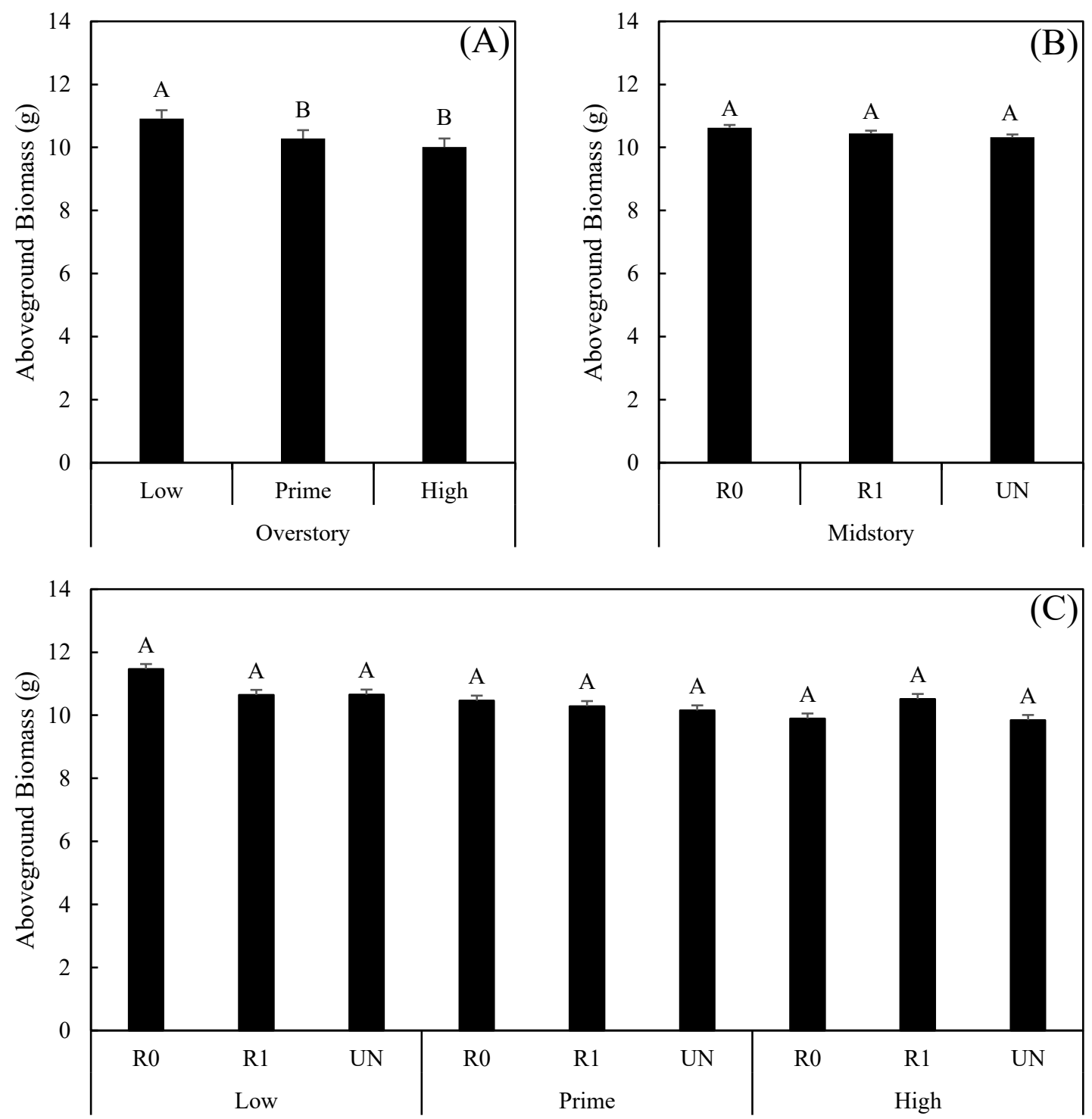

Figure 5.2 Biomass Response to Fixed Effects.

Average biomass (g dry wt) of longleaf seedlings within (A) overstory groupings ( $<12$ $\mathrm{m}^{2} /$ ha (low), $12-18 \mathrm{~m}^{2} / \mathrm{ha}$ (prime), $>18 \mathrm{~m}^{2} / \mathrm{ha}$ (high)), (B) midstory treatments (treating prior to planting (R0), treating after one year (R1), or left untreated (UN)), and (C) midstory treatments within overstory groupings. Error bars represent 1 Standard Error. Bars with differing letters denote a significant difference at the 0.05 level from a TukeyKramer MCP. 


\subsection{Brown Spot Needle Blight Infection}

Seedling brown spot infection was best explained by a model containing the fixed effect of overstory groupings, and the random effect of Block (Table 5.1). BSNB infection rates in overstory groupings differed significantly $(\mathrm{p}=0.0014$; Table 5.1), with infection rates being significantly lower in the high overstory density grouping $(35 \pm 19$ $\%$ ) compared to either prime (45 $\pm 26 \%$; Figure 5.3) or low (49 $\pm 31 \%$; Figure 5.3) density groupings. Among midstory treatments, (R1) had the greatest percent BSNB infection (48\%). Midstory treatments and their interaction with overstory groupings did not significantly impact BSNB infection rates, and where therefore not included in the

model (Table 5.1). In contrast, Block significantly influenced seedling infection rates $(\mathrm{p}<$ 0.0001; Table 5.1), with rates ranging from $25 \%$ to $79 \%$ among Blocks. (Individual Block estimates are available in Table A.3.) 

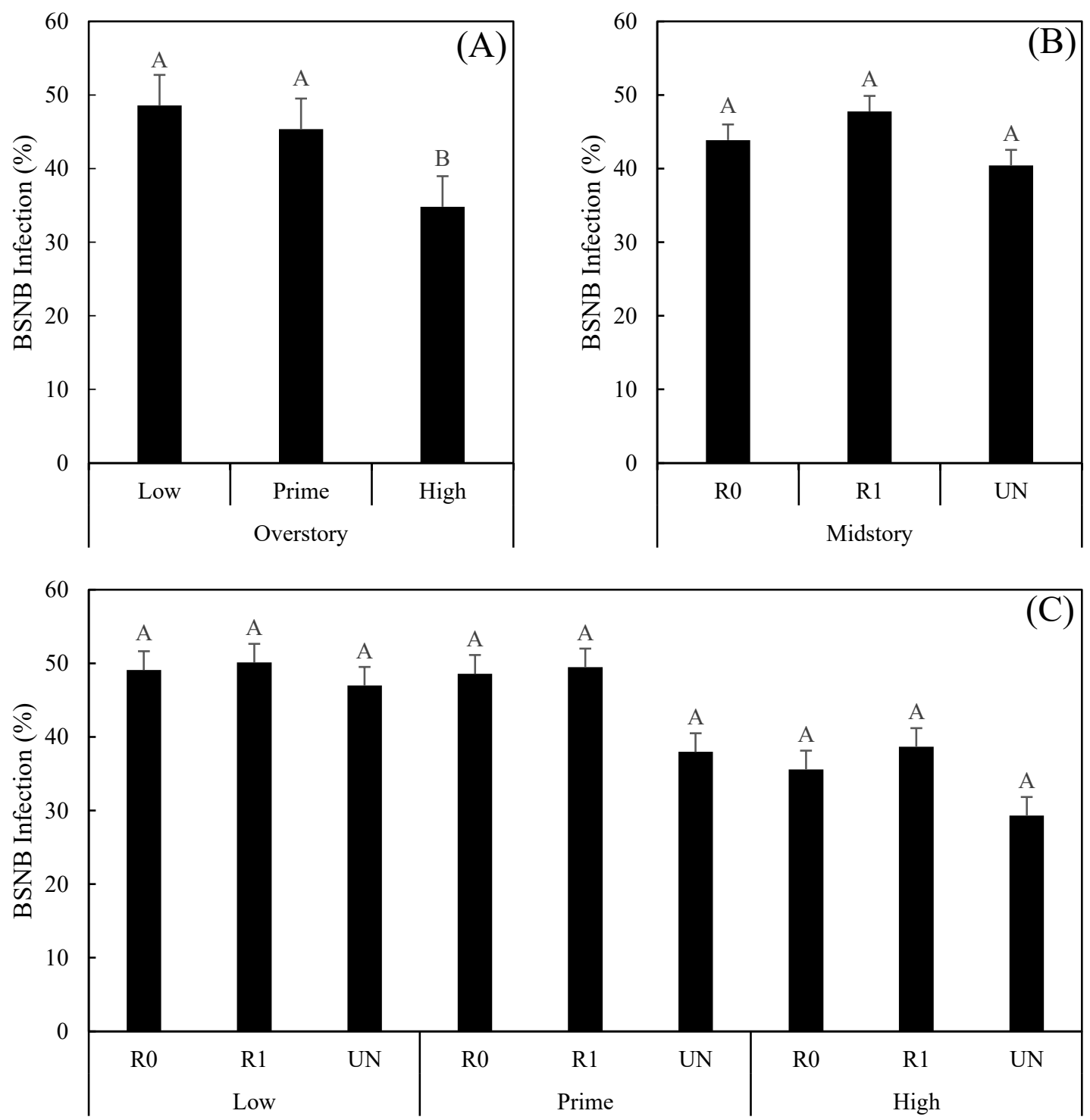

Figure 5.3 Brown Spot Needle Blight Infection Response to Fixed Effects.

Average BSNB infection (\%) of longleaf seedlings within (A) overstory groupings $(<12$ $\mathrm{m}^{2} /$ ha (low), $12-18 \mathrm{~m}^{2} / \mathrm{ha}$ (prime), $>18 \mathrm{~m}^{2} / \mathrm{ha}$ (high)), (B) midstory treatments (treating prior to planting (R0), treating after one year (R1), or left untreated (UN)), and (C) midstory treatments within overstory groupings. Error bars represent 1 Standard Error. Bars with differing letters denote a significant difference at the 0.05 level from a TukeyKramer MCP. 


\subsection{Mechanistic Correlations}

Overall, seedling survival and growth were more strongly associated with soil moisture than light availability (Figures $5.4 \& 5.5$ ). While overstory density was not significantly correlated to soil moisture, it did have a significant, weakly positive correlation with seedling predawn moisture stress $(\rho=-0.28619, p=0.0062$; Figure 5.4). The presence of midstory hardwoods did not significantly affect seedling predawn moisture stress or soil moisture availability. Soil moisture also did not correlate significantly to predawn moisture stress. The only factors that correlated significantly (weakly) with soil moisture were percent wiregrass $(\rho=-0.2582, p=0.0410)$ and percent bare soil $(\rho=0.26597, p=0.0351)$. Seedling survival had a significant, moderately positive correlation with predawn moisture stress $(\rho=0.30337, p=0.0037$; Figure 5.4). Seedling biomass had a significant, moderately positive correlation with both predawn water potentials $(\rho=0.29743, p=0.0046$; Figure 5.4) and summer transpiration rates $(\rho$ $=0.52827, \mathrm{p}<0.0001 ;$ Figure 5.4). Predawn moisture stress and transpiration rates did not change significantly from March to July. 

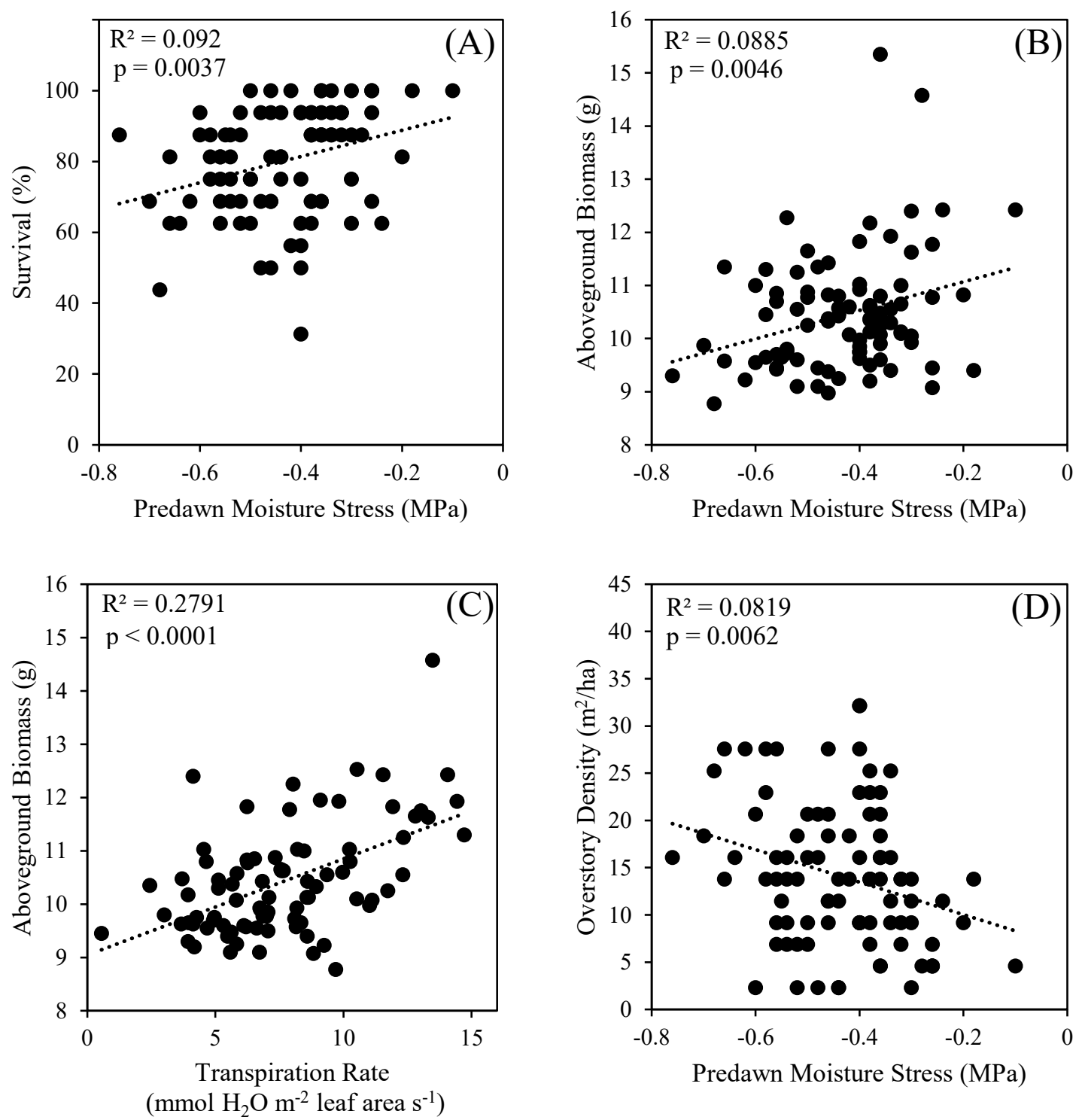

Figure 5.4 Pearson Correlation Analyses for Moisture Dynamics.

Correlations include survival and predawn moisture stress (A), aboveground biomass and predawn moisture stress (B), aboveground biomass and transpiration rate (C), and overstory density and predawn moisture stress (D). It should be noted that predawn potentials are negative values, so a more negative predawn value indicates greater moisture stress. 
Light above (but not below) the oak midstory had a significant but weak negative correlation with overstory density $(\rho=-0.18165, \mathrm{p}=0.0350$; Figure 5.5). Overstory density also had a significant, but again weak, negative correlation with seedling photosynthetic rate $(\rho=-0.25015, p=0.0195$; Figure 5.5). Midstory treatments did not significantly affect soil temperature at either depth or seedling photosynthetic rate. However, light at the seedling level was significantly reduced by an average of $20 \%$ under a hardwood midstory $(\mathrm{p}=0.0117)$. Light levels above and below the hardwood midstory were not significantly correlated to soil temperature $(15 \mathrm{~cm}$ and $30 \mathrm{~cm})$, photosynthetic rates, or BSNB infection rates. While photosynthetic rate was not significantly correlated to seedling survival or BSNB infections rate, it did have a significant, moderately positive correlation with seedling biomass $(\rho=0.47111, \mathrm{p}<$ 0.0001; Figure 5.5). Transpiration rates did not change significantly from March to July. 

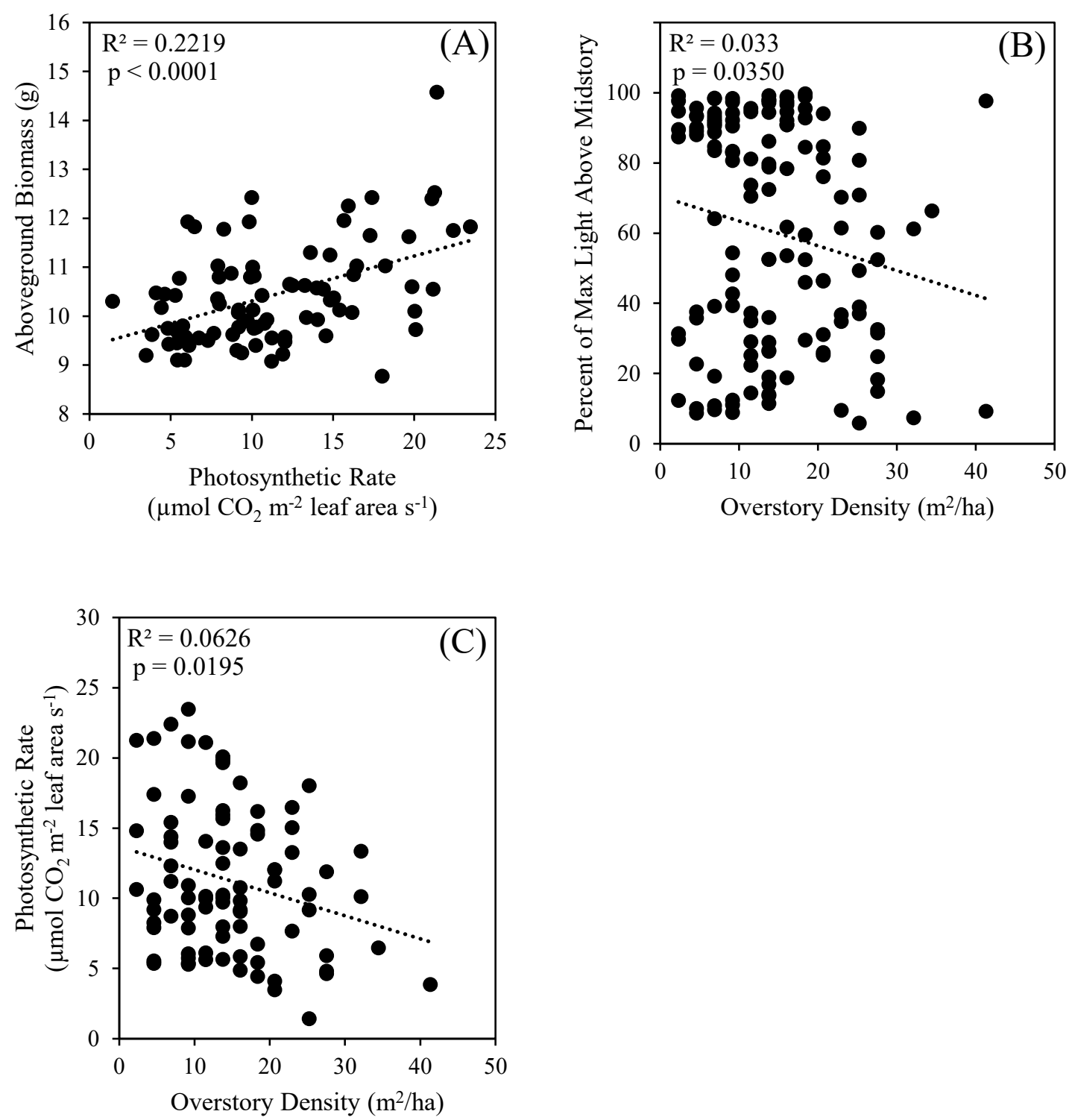

Figure 5.5 Pearson Correlation Analyses for Light Dynamics.

Correlations include aboveground biomass and photosynthetic rate (A), light above the midstory and overstory density (B), and photosynthetic rate and overstory density (C). 


\section{CHAPTER VI}

\section{DISCUSSION}

\subsection{RCW Overstory Management Guidelines}

The variable overstory density of this site provided a useful opportunity to assess not only the regeneration dynamics of longleaf pine on a xeric site, but also how these dynamics function across a range of overstory density in the context of RCW management guidelines. Because longleaf pine is a shade intolerant species (Burns \& Honkala 1990), and belowground competition has been shown to inhibit seedling growth (Brockway \& Outcalt 1998), the influence of the overstory can be a significant negative factor on longleaf regeneration. By assessing the impact of overstory density on longleaf survival, growth, and BSNB infection, we may better understand the long-term impacts of managing for RCW habitat.

Longleaf pine seedling survival exhibited an inverse relationship with overstory density, where survival decreased as overstory density increased. This result echoes my hypothesis as I expected competitive effects to be more apparent at high overstory density than low overstory density (as seen in Grace \& Platt 1995). This competitive effect may be caused by belowground interactions (Brockway \& Outcalt 1998), as even at the high overstory densities the site was not light limited (Jose et al. 2003). In Jose et al. (2003), "high light" levels were defined as $800-900 \mu \mathrm{mol} \mathrm{m}^{-2} \mathrm{~s}^{-1}$, and light levels in my study in the high overstory grouping were an average of $1045 \mu \mathrm{mol} \mathrm{m} \mathrm{m}^{-2} \mathrm{~s}^{-1}$. However, 
the spatial variability of the overstory significantly affects light availability at the forest floor (Battaglia et al. 2002). A similar study conducted in southwestern Georgia, with similar site conditions, did not find a significant relationship between survival and overstory density (Palik et al. 1997). However, Palik et al. (1997) reported on survival after only one growing season, whereas I assessed survival after two growing seasons. Therefore, a single growing season may not have been sufficient to see the competitive effects of a longleaf overstory on seedling survival, as they have been shown to persist in low resource environments for up to ten years (Burns \& Honkala 1990). Another study, also conducted in southwestern Georgia with similar site conditions, found the overstory to facilitate seedling survival versus gaps (Pecot et al. 2007). While their study showed a general facilitative effect of the overstory in relation to canopy gaps, my study refines the effect of a range of overstory densities, and their effects on seedling survival within the context of RCW guidelines. A third study, conducted on similar site conditions, also showed increasing seedling survival with decreasing overstory density (Grace \& Platt 1995). Overall, in terms of RCW guidelines, my study showed seedling survival rates can be increased within the first two years following planting by reducing overstory density.

However, my site was not burned during the two years between seedling planting and measurements. Overstory longleaf litter has been demonstrated to result in increased fire intensity (Brockway \& Outcalt 1998), as well as increased seedling mortality (Grace \& Platt 1995). Therefore, I would expect lower survival rates in the high overstory grouping in the presence of fire.

Aboveground seedling biomass exhibited the same relationship as survival, where growth decreased as overstory density increased. Again, this result supports my 
hypothesis as I expected to see a competitive effect of high overstory density limiting seedling growth. These results agree with other studies (Palik et al. 1997, Pecot et al. 2007, Grace \& Platt 1995), which also reported an inverse trend between longleaf seedling growth and overstory density. My results show that recommended RCW overstory densities are significantly limiting seedling growth on xeric sites within the first two years following planting.

BSNB infection rates showed an inverse relationship with overstory density, where BSNB infection rate decreased as overstory density increased. This supports my hypothesis based on the literature (Kais 1975), stating that BSNB infection was more prevalent in higher light conditions due to open stomata providing an entrance for the fungus into longleaf seedling needles. However, these results are only indicative of the first two years following planting. This study does not show how these overstory groupings may affect the length of the grass stage, which is necessary to consider as it has been shown that increasing the length of the grass stage can lead to greater BSNBinduced seedling mortality (Boyer 1975). Extending the duration of this study may show potential tradeoffs, regarding BSNB infection rates, due to maintaining high overstory densities.

\subsection{Midstory Treatments}

Burning midstory hardwoods is common to both RCW management and traditional silvicultural methods. However, the consequences of these practices on longleaf seedling regeneration on xeric sites are not well understood. While competitive interactions between longleaf seedlings and midstory hardwoods are certainly prevalent (Brockway \& Outcalt 2000, Provencher et al. 2001), the facilitative interactions between 
midstory hardwoods and longleaf seedlings have not been thoroughly investigated (Wahlenburg 1946, Gaines 1950, Espeleta et al. 2004, Loudermilk et al. 2016). Understanding the role of midstory hardwoods on xeric sites is critical for future restoration efforts, as the current practice of burning hardwood midstories may be inadvertently contributing to longleaf regeneration failures.

Untreated plots (UN) exhibited greatest longleaf seedling survival, which supports my hypothesis that survival would be greatest underneath the hardwood midstory, and may be indicative of facilitative interactions between longleaf seedlings and midstory hardwoods. Additionally, facilitation may occur soon after germination, a life history stage not considered in this study. Seedlings in treatment (R1) had the lowest survival. This may be an example of seedlings adapting to conditions underneath a hardwood midstory their first year following planting, and the removal of the midstory one year post establishment potentially illustrates a complex inter-specific interaction between longleaf seedlings and midstory hardwoods being disrupted (Diaz et al. 2003).

Additionally, the density of midstory hardwoods may determine whether interactions are competitive or facilitative. Loudermilk et al. (2016) reported facilitative interactions between the hardwood midstory and seedling survival for midstory densities up to 1,400 stems per hectare. However, the average midstory density at my site was 6,228 stems per hectare. Extending the duration of this study would serve two purposes: one, to better separate the effects of the midstory treatments, and two, to reach a point when facilitative effects shift to competitive effects. While the presence of midstory hardwoods may initially be facilitative, I expect the relationship to become competitive 
once longleaf seedlings begin competing for belowground growing space, as has been shown with mature longleaf pine (Brockway \& Outcalt 1998).

Biomass results agreed with my hypothesis that seedling growth would be greatest when no midstory was present (R0), and that growth would be lowest in untreated plots (UN). The trend of growth averages shows a competitive relationship between the hardwood midstory and longleaf seedlings, illustrating the motivation for traditional removal of the hardwood midstory. However, these results do not show whether this competitive interaction is for moisture or for light, demonstrating the need to mechanistically identify the limiting resource on xeric sites.

Brown spot needle blight infection rates showed an unexpected trend, with greatest BSNB infection rates in plots treated after one year (R1). My results partially agree with my hypothesis, where infection rates were lowest in (UN) plots. Again, this echoes the results of Kais (1975), which showed reduced infection rates in lower light conditions due to stomatal closure, and therefore fewer entrances into the needles for the fungus. While I expected infection rates to be highest in (R0) plots due to higher light availability, they were instead highest in (R1) plots. As noted in the survival responses to midstory treatments, seedlings in the (R1) plots likely experienced a disruption to the facilitative relationship with midstory hardwoods (Diaz et al. 2013). This disruption may have weakened seedlings by removing the facilitative relationship with the midstory, thereby making them more susceptible to BSNB infection. Additionally, (R1) plots experienced a shift to higher light availability during a year with above-average precipitation (1135 $\mathrm{mm}$ in 2017, compared to $1084 \mathrm{~mm}$ average). This combination of increased light and precipitation could have led to increased BSNB infection rates (Kais 
1975). While assessing causes of seedling mortality was not an aim of this study, it is notable that survival was lowest in the midstory treatment (R1) with the greatest BSNB infection rates. Additionally, the relationship between BSNB infection rates and survival showed a significant, weakly negative correlation. Due to the design of this experiment, I was not able to determine the cause of mortality of longleaf seedlings. However, the factors of overstory competition and BSNB infection rates may have impacted mortality.

\subsection{Mechanistic Correlations}

Light and moisture dynamics were assessed to better understand their effects on longleaf seedling physiology on xeric sites. I selected physiological measurements because they can assess specific processes of the seedling on a short timescale, compared to the integrated measure of growth. While both moisture and light are critical components of seedling survival and growth (Pecot et al. 2007), I saw a much stronger relationship between longleaf regeneration and moisture dynamics at this site.

Regarding moisture dynamics, neither overstory density nor the presence of midstory hardwoods significantly affected soil moisture availability. This is not surprising, as the frequency of measurements (monthly) was likely not adequate to capture soil moisture fluctuations. High bare soil cover correlated to increased soil moisture and high wiregrass cover correlated to decreased soil moisture, indicating that wiregrass reduces soil moisture. Additionally, these correlations may be a result of soil bulk density, as organic matter content has been shown to relate to lower bulk density (Hossain et al. 2015) and, therefore, less soil water holding capacity. Sandy soils have low bulk density compared to silt or clay soils, and the addition of organic matter from wiregrass could reduce the soil bulk density further. The positive relationship between 
bare soil and soil moisture contradicts a litter removal study that found decreased soil moisture when all litter was removed (Ginter et al. 1979). However, the Ginter et al. (1979) study did not assess understory composition and its effect on soil moisture. Although my plot composition measurements were only a snapshot of the vegetation during 2017 , they were likely more useful regarding soil moisture, as the physiological measurements were limited in both sample size and frequency.

My predawn moisture stress results mimicked values found in other studies on xeric sites (Addington et al. 2006, Brockway \& Outcalt 1998), as seedlings experienced greater moisture stress under higher overstory densities. In turn, plots with seedlings experiencing greater moisture stress had lower survival and growth. Even in mature longleaf pine, predawn moisture stress is suggested as a potential cause of reduction in growth (Ginter et al. 1979). While my study did not show a significant correlation between midstory hardwoods and seedling moisture stress, this has been demonstrated elsewhere (Loudermilk et al. 2016). This discrepancy could be due to yearly precipitation variability. Precipitation at my site was above average during the year that physiological measurements were taken (1084 mm yearly average, compared to $1135 \mathrm{~mm}$ in 2017). From the stress gradient hypothesis (Maestre et al. 2009), I would expect more obvious facilitative interactions under higher stress conditions (e.g. less precipitation on xeric sites). Therefore, the above-average precipitation of 2017 could have potentially reduced the occurrence of facilitative interactions.

Seedling transpiration rates illustrated inhibited seedling growth due to low moisture conditions, and my results are comparable to other studies with similar findings (Jose et al. 2003). However, the frequency of transpiration rate measurements was likely 
not adequate to capture the effect of transpiration on longleaf seedling survival. With the exception of midstory hardwoods, my hypotheses were validated by my correlation analyses showing greater competition for moisture at higher overstory densities (also seen in Pecot et al. 2007, Grace \& Platt 1995), and its detrimental effect on seedling survival and growth.

Light dynamics showed fewer significant correlations with site biological measurements than did moisture dynamics, but some important relationships were identified. As expected, light availability above the hardwood midstory decreased with increasing overstory density, as has been demonstrated elsewhere (Battaglia et al. 2002, Palik et al. 2003). Increasing overstory density also significantly reduced seedling photosynthetic rates. However, photosynthetic rates were not significantly correlated to light availability. These results show that overstory density reduces seedling photosynthetic rates. This is likely due to the competitive moisture effects presented earlier, emphasizing the importance of considering moisture dynamics as well as light availability on xeric sites. However, the disconnect between light availability and photosynthetic rates could be due to the high variability of light quality in longleaf pine forests (Pecot et al. 2005). Additionally, light availability (both above and below the midstory) was not significantly correlated to soil temperature (depths of $15 \mathrm{~cm}$ and 30 $\mathrm{cm}$ ) or BSNB infection rates. Again, this is not surprising, as the frequency of measurements (monthly) was not adequate to illuminate soil temperature fluctuations. I did not see a direct relationship between light availability and BSNB infection, as I would have expected from the results of Kais (1975). This is potentially due to an interaction with the moisture dynamics of the site. While BSNB infection has been shown to 
increase with light, it has also been shown to increase with increasing humidity (Kais 1975). The increased humidity shortens the incubation period and greatly increases the degree of infection. However, BSNB has been reported to enter through longleaf stomata, and, as such, higher light levels that lead to greater stomatal opening may increase BSNB infection rates. Therefore, increased light alone may not have been sufficient to increase BSNB infection rates. Finally, seedling photosynthetic rates correlated significantly with seedling biomass, but not seedling survival. This relationship echoes the results of overstory density, as increased photosynthetic rates allow for an increased potential for growth.

Considering moisture dynamics and light dynamics in combination is necessary to understand the effects of overstory density and midstory hardwoods on longleaf regeneration. Moisture availability affected both seedling survival and growth, while light availability only affected seedling growth. These results partially agree with my hypotheses that this xeric site was not light limited, and longleaf regeneration was primarily influenced by moisture stress. 


\section{CHAPTER VII MANAGEMENT IMPLICATIONS}

Traditional management practices for longleaf pine regeneration are based upon its shade intolerance, but more attention is being given to the moisture dynamics present in the longleaf ecosystem due to regeneration failures and an increased understanding of belowground interactions (Brockway \& Outcalt 1998, Pecot et al. 2007). These dynamics are particularly important on xeric sites where moisture stress is a common occurrence. While many sites manage for RCW habitat, there has been little consideration of the effects of RCW habitat management on longleaf pine regeneration. This study investigated two current longleaf management practices: retaining an overstory density of 12 to $18 \mathrm{~m}^{2} /$ ha for RCW habitat, and the removal of midstory hardwoods to provide an open canopy for RCW movement. While the facilitative role of midstory hardwoods has been a topic of interest (Wahlenburg 1946, Espeleta et al. 2004, Loudermilk et al. 2016), few have assessed this mechanistically in combination with overstory density management (Pecot et al. 2007).

An important note is that the duration of this study was only two years and did not quantify long-term (i.e. beyond longleaf grass stage) effects of overstory density and midstory treatments. My results indicate that managing overstory densities for RCW habitat on xeric sites is negatively impacting the survival and growth of longleaf seedlings. Additionally, longleaf seedling survival was greatest underneath a hardwood 
midstory, and the greatest growth occurred without a hardwood midstory. While longleaf regeneration is not the primary objective when managing for $\mathrm{RCW}$ habitat, my results indicate that burning the hardwood midstory may not necessarily help longleaf regeneration. Future reports that extend the duration of this study may distinctly separate the effects of midstory treatments on seedling regeneration.

However, these results also have implications for prescribed fire. Leaving midstory hardwoods untreated for an extended period will make them resistant to control through prescribed fire; thus, midstory removal may require chemical or mechanical treatment. Additionally, the absence of fire may lead to a build-up of fuels on the forest floor, resulting in increased fire intensity. Therefore, determining when midstory hardwoods are still manageable with fire, but also continue to provide facilitative effects to longleaf seedlings, is a critical need for longleaf ecosystem management on xeric sites.

Land management plans often incorporate multiple use objectives, and integrating the effects of soil type into these objectives is essential for managing longleaf pine forests. From this study, early results suggest that current overstory density management practices for RCW habitat are proving detrimental to longleaf seedling survival and growth in the context of artificial regeneration with containerized longleaf seedlings. By reducing overstory density guidelines for $\mathrm{RCW}$, successful longleaf regeneration can be improved. Additionally, retaining midstory hardwoods for a period after seedling establishment has a beneficial impact on seedling survival. Further investigation of the role of midstory hardwoods on longleaf regeneration on xeric sites is essential to the future sustainability of the longleaf ecosystem in the context of RCW habitat. 


\section{REFERENCES}

Abrams, M. D. (1990). Adaptations and responses to drought in Quercus species of North America. Tree Physiology 7: 227-238.

Addington, R. N., Donovan, L. A., Michell, R. J., Vose, J. M., Pecot, S. D., Jack, S. B., Hacke, U. G., Sperry, J. S., Oren, R. (2006). Adjustments in hydraulic architecture of Pinus palustris maintain similar stomatal conductance in xeric and mesic habitats. Plant, Cell and Evironment 29: 535-545.

Aerts, R. (1999). Interspecific competition in natural plant communities: mechanisms, trade-offs and plant-soil feedbacks. Journal of Experimental Botany 50: 29-37.

Allen, R. M. (1954). Shade may improve longleaf survival. United States Forest Service, Southern Forest Experiment Station, Southern Forestry Notes 90: 3-4.

Barnett, J. P., Brissette, J. C. (1986). Producing southern pine seedlings in containers. USDA Forest Service Gen. Technical Report SO-59.

Boyer, W. D. (1975). Development of brown-spot infection in longleaf pine seedlings stands. New Orleans (LA): USDA Forest Service, Southern Forest Experiment Station. Research Paper SO-108. 10 p.

Boyer, W. D., Peterson, D. W. (1983). Longleaf pine. In: Burns, R. M. (Tech. Comp.), Silvicultural Systems for the Major Forest Types of the United States. USDA Forest Service Agricultural Handbook, vol. 445. Washington, D. C., pp. 153-156.

Brockway, D. G., Lewis, C. E. (1997). Long-term effects of dormant-season prescribed fire on plant community diversity, structure and productivity in a longleaf pine wiregrass ecosystem. Forest Ecology and Management 96: 167-183.

Brockway, D. G., Outcalt, K. W. (1998). Gap-phase regeneration in longleaf pine wiregrass ecosystems. Forest Ecology and Management 106: 125-139.

Brockway, D. G., K. W. Outcalt. (2000). Restoring longleaf pine wiregrass ecosystems: hexazinone application enhances effects of prescribed fire. Forest Ecology and Management 137: 121-138. 
Brockway, D.G., Outcalt, K.W., Boyer, W.D. (2006). Longleaf pine regeneration ecology and methods. In: Jose, S., Jokela, E.J., Miller, D.L. (Eds.), The Longleaf Pine Ecosystem: Ecology, Silviculture and Restoration. Springer Science, New York, pp. 95-133.

Burnham, K. P., Anderson, D. R. (2004). Multimodal inference: Understanding AIC and BIC in model selection. Sociological Methods Research 33: 261-304.

Burns, Russell M., and Barbara H. Honkala, tech. coords. (1990). Silvics of North America: 1. Conifers; 2. Hardwoods. Agriculture Handbook 654. U.S. Department of Agriculture, Forest Service, Washington, DC. vol.2, 877

Brown, J.K. (2000). Introduction and fire regimes. In: Brown, J.K., Smith, J.K. (Eds.). Wildland Fire in Ecosystems: Effects of Fire on Flora. USDA Forest Service RMRS-GTR-42, vol. 2, pp. 1-8.

Bruce, D. (1951). Fire resistance of longleaf pine seedlings. Journal of Forestry 49: 739740.

Caldwell, M. M., Richards, J. H. (1989). Hydraulic lift: water efflux from upper roots improves effectiveness of water uptake by deep roots. Oecologia 79: 1-5.

Callaway, R. M., Walker, L. R. (1997). Competition and facilitation: a synthetic approach to interactions in plant communities. Ecology 78: 1958-1965.

Cavender-Bares, J., Kitajima, K., Bazzaz, F. A. (2004). Multiple trait associations in relation to habitat differentiation among 17 Floridian oak species. Ecological Monographs 74:635-662.

Conn, C., Dighton, J. (2000). Litter quality influences on decomposition, ectomycorrhizal community structure and mycorrhizal root surface acid phosphatase activity. Soil Biology \& Biochemistry 32: 489-496.

Connor, R. N., Rudolph, D. C. (1995). Excavation dynamics and use patterns of redcockaded woodpecker cavities: relationships with cooperative breeding. In: Kulhavy, D.L., Hooper, R.G., Costa, R. (Eds.), Red-cockaded Woodpecker: Recovery, Ecology and Management, Center for Applied Studies in Forestry. Stephen F. Austin University, pp. 343-352.

Conway, W. C., Smith, L. M., Bergan, J. F. (2002). Potential allelopathic interference by the exotic Chinese tallow tree (Sapium sebiferum). The American Midland Naturalist 148: 43-53.

Costa, R. (1992). Draft Red-cockaded woodpecker Procedures Manual for Private Lands. US Fish and Wildlife Service, Atlanta, Georgia. 
Diaz, S., Symstad, A. J., Chapin, F. S. III, Wardle, D. A., Huenneke, L. F. (2003). Functional diversity revealed by removal experiments. Trends in Ecology and Evolution 18: 140-146.

Diemer, J. E. (1986). The ecology and management of the gopher tortoise in the southeastern United States. Herpetologica 42: 125-133.

Doster, R., James, D. (1998). Home range size and foraging habitat of red-cockaded woodpeckers in the Ouachita Mountains of Arkansas. The Wilson Bulletin 110: 110-117.

Engstrom, R.T. (1993). Characteristic mammals and birds of longleaf pine forests. Tall Timbers Fire Ecology Conference 18: 127-138.

Espeleta, J. F., Donovan, L. A. (2002). Fine root demography and morphology in response to soil resources availability among xeric and mesic sandhill tree species. Functional Ecology 16: 113-121.

Espeleta, J. F., West, J. B., Donovan, L. A. (2004). Species-specific patterns of hydraulic lift in co-occurring adult trees and grasses in a sandhill community. Oecologica 138: $341-349$.

Facelli, J. M., Pickett, S. T. A. (1991). Plant litter - its dynamics and effects on plant community structure. Botanical Review 57: 1-32.

Fowells, H. A., comp. (1965). Silvics of forest trees of the United States. U.S. Department of Agriculture, Agriculture Handbook 271. Washington, D. C. 762 p.

Fox, T. R., Jokela, E. J., Allen, H. L. (2007). The development of pine plantation silviculture in the southern United States. Journal of Forestry 105: 337-347.

Fox, C. W., Waddell, K. J., Groeters, F. R., Mousseau, T. A. (1997). Variation in budbreak phenology affects the distribution of a leafmining beetle (Brachys tessellatus) on turkey oak (Quercus laevis). Ecoscience 4: 480-489.

Franco, A. C., Nobel, P. S. (1989). Effect of nurse plants on the microhabitat and growth of cacti. Journal of Ecology 77: 870-886.

Frost, C. C. (1993). Four centuries of changing landscape patterns in the longleaf pine ecosystem. Tall Timbers Fire Ecology Conference 18: 17-44.

Gaines, E. M. (1950). Scrub oak helps longleaf seedlings on deep sand. United States Forest Service, Southern Forest Experiment Station, Southern Forestry Note 69. 
Gagnon, J. L., Jokela, E. J., Moser, W. K., Huber, D. A. (2004). Characteristics of gaps and natural regeneration in mature longleaf pine flatwoods ecosystems. Forest Ecology and Management 187: 373-380.

Gilliam, F. S., Platt, W. J. (1999). Effects of long-term fire exclusion on tree species composition and stand structure in an old-growth Pinus palustris (Longleaf pine) forest. Plant Ecology 140: 15-26.

Ginter, D. L., McLeod, K. W., Sherrod, C. Jr. (1979). Water stress in longleaf pine induced by litter removal. Forest Ecology and Management 2: 13-20.

Grace, S. L., Platt, W. J. (1995). Effects of adult tree density and fire on the demography of pregrass stage juvenile longleaf pine (Pinus palustris Mill.). Journal of Ecology 83: 75-86.

Greenlee, J. T., Callaway, R. M. (1996). Abiotic stress and the relative importance of interference and facilitation in montane bunchgrass communities in western Montana. The American Naturalist 148: 386-396.

Grier, C. C., Running, S. W. (1977). Leaf area of mature northwestern coniferous forests: relation to site water balance. Ecology 58: 893-899.

Hare, R. C. (1965). Contribution of bark to fire resistance of southern trees. Journal of Forestry 63: 248-251.

Harrington, T. B., Edwards, M. B. (1999). Understory vegetation, resource availability, and litterfall responses to pine thinning and woody vegetation control in longleaf pine plantations. Canadian Journal of Forest Research 29: 1055-1064.

Harrington, T. B., Minogue, P. J., Lauer, D. K., Ezell, A. W. (1998). Two-year development of southern pine seedlings and associated vegetation following spray-and-burn site preparation with imazapyr alone or in mixture with other herbicides. New Forests 15: 89-106.

Henry, V. G. (1989). Guidelines for preparation of biological assessments and evaluations for the red-cockaded woodpecker. U.S. Fish and Wildlife Service, SE Reg., Atlanta, Georgia.

Hiers, J. K., Walters, J. R., Mitchell, R. J., Varner, J. M., Conner, L. M., Blanc, L. A., Stowe, J. (2014). Ecological value of retaining pyrophytic oaks in longleaf pine ecosystems. The Journal of Wildlife Management 78: 383-393.

Holmgren, M., Scheffer, M. (2010). Strong facilitation in mild environments: the stress gradient hypothesis revisited. Journal of Ecology 98: 1269-1275. 
Holmgren, M., Scheffer, M., Huston, M. A. (1997). The interplay of facilitation and competition in plant communities. Ecology 78: 1966-1975.

Hossain, M. F., Chen, W., Zhang, Y. (2015). Bulk density of mineral and organic soils in the Canada's arctic and sub-arctic. Information Processing in Agriculture 2: $183-$ 190.

Johnson, A.S., Hale, P.E., (2002). The historical foundations of prescribed burning for wildlife: a southeastern perspective. In: Ford, W.M., Russell, K.R., Moorman, C.E. (Eds.), The Role of Fire in Nongame Wildlife Management and Community Restoration: Traditional Uses and New Directions. USDA Forest Service Gen. Technical Report NE-288, pp. 11-23.

Jose, S., Jokela, E. J., Miller, D. L. eds. (2006) The Longleaf Pine Ecosystem: Ecology, Silviculture, and Restoration. New York: Springer. Print.

Jose, S., Merritt, S., Ramsay, C. L. (2003). Growth, nutrition, photosynthesis and transpiration responses of longleaf pine seedlings to light, water and nitrogen. Forest Ecology and Management 180: 335-344.

Kais, A. G. (1975). Environmental factors affecting brown spot infection on longleaf pine. Phytopathology 65: 1389-1392.

Kane, J. M., Varner, J. M., Hiers, J. K. (2008). The burning characteristics in southeastern oaks: discriminating fire facilitators from fire impeders. Forest Ecology and Management 256: 2039-2045.

Keeley, J.E., Zedler, P.H. (1998). Evolution of life histories in Pinus. In Ecology and Biogeography of Pinus. Richardson, D.M. (Ed). Cambridge University Press: Cambridge, UK. pp. 219-250.

Kellman, M., Kading, M. (1992). Facilitation of tree seedling establishment in a sand dune succession. Journal of Vegetation Science 3: 679-688.

Koenig, W. D., Knops, J. M. (1998). Scale of mast-seeding and tree-ring growth. Nature 396: 225-226.

Li, Z., Wang, Q., Ruan, X., Pan, C., Jiang, D. (2010). Phenolics and plant allelopathy. Molecules 15: 8933-8952.

Lipscomb, D. J. (1989). Impacts of feral hogs on longleaf pine regeneration. Southern Journal of Applied Forestry 13: 177-181. 
Loudermilk, E. L., Hiers, J. K., Pokwinski, S., O’Brien, J. J., Barnett, A., Mitchell, R. J. (2016). The path back: oaks (Quercus spp.) facilitate longleaf pine (Pinus palustris) seedling establishment in xeric sites. Ecosphere 7: 1-14.

Maestre, F. T., Callaway, R. M., Valladeres, F., Lortie, C. J. (2009). Refining the stressgradient hypothesis for competition and facilitation in plant communities. Journal of Ecology 97: 199-205.

Mattoon, W. R. (1922). Longleaf pine. Bull, No, 1061. USDA Washington, D. C. 50 p.

Mayer, J. J., Nelson, E. A., Wike, L. D. (2000). Selective depredation of planted hardwood seedlings by wild pigs in a wetland restoration area. Ecological Engineering 15: S79-S85.

McClanahan, T. R. (1986). Seed dispersal from vegetation islands. Ecological Modelling 32: 301-309.

McGuire, J. P., Mitchell, R. J., Moser, E. B., Pecot, S. D., Gjerstad, D. H., Hedman, C. W. (2001). Gaps in a gappy forest: plant resources, longleaf pine regeneration, and understory response to tree removal in longleaf pine savannas. Canadian Journal of Forest Research 31: 765-778.

Means, D. B. (1996). Longleaf pine forest, going, going. Eastern old-growth forests: prospects for rediscovery and recovery, 210-229.

Mitchell, R. J., Hiers, J. K., O’Brien, J. J., Jack, S. B., Engstrom, R. T. (2006). Silviculture that sustains: the nexus between silviculture, frequent prescribed fire, and conservation biodiversity in longleaf pine forests of the southeastern United States. Canadian Journal of Forest Research 36: 2724-2736.

Mohr, C. (1896). The timber pines of the southern United States. USDA Division of Forestry, Bull. No. 13, Washington, D. C. 176 p.

Noss, R. F., LaRoe, E. T., Scott, J. M., (1995). Endangered ecosystems of the United States: a preliminary assessment of loss and degradation. USDI National Biological Service, Biological Report 28.

Nowacki, G. J., Abrams, M. D. (2008). The demise of fire and "mesophication" of forests in the eastern United States. Bioscience 58: 123-138.

Outcalt, K. W. (2000). The longleaf pine ecosystem of the south. Native Plants Journal 1: $42-53$. 
Outcalt, K. W., Sheffield, R. M. (1996). The longleaf pine forest: trends and current conditions. USDA Forest Service Southern Research Station. Resource Bulletin SRS-9.

Palik, B. J., Mitchell, R. J., Houseal, G., Pederson, N. (1997). Effects of canopy structure on resource availability and seedling responses in a longleaf pine ecosystem. Canadian Journal of Forest Research 27: 1458-1464.

Palik, B., Mitchell, R. J., Pecot, S., Battaglia, M., Pu, M. (2003). Spatial distribution of overstory retention influences resources and growth of longleaf pine seedlings. Ecological Applications 13: 674-686.

Parrish, J. A. D., Bazzaz, F. A. (1982). Competitive interactions in plant communities of different successional ages. Ecology 63: 314-320.

Pecot, S. D., Horsley, S. B., Battaglia, M.A., Mitchell, R. J. (2005). The influence of canopy, sky condition, and solar angle on light quality in a longleaf pine woodland. Canadian Journal of Forest Research 35: 1356-1366.

Pecot, S. D., Mitchell, R. J., Palik, B. J., Moser, E. B., Hiers, J. K. (2007). Competitive responses of seedlings and understory plants in longleaf pine woodlands: separating canopy influences above and below ground. Canadian Journal of Forest Research 37: 634-648.

Pessin, L. J. (1938). The effect of vegetation on the growth of longleaf pine seedlings. Ecological Monographs 8: 115-149.

Phelps, W. R., Kais, A. G., Nicholls, T. H. (1978). Brown-spot needle blight of pines. USDA Forest Insect \& Disease Leaflet 44.

Provencher, L., Herring, B. J., Gordon, D. R., Rodgers H. L., Tanner G. W., Hardesty, J. L., Brennan, L. A., Litt, A. R. (2001). Longleaf pine and oak responses to hardwood reduction techniques in fire-suppressed sandhills in northwest Florida. Forest Ecology and Management 148: 63-77.

Ren, H., Yang, L., Liu, N. (2008). Nurse plant theory and its application in ecological restoration in lower subtropics of China. Progress in Natural Science 18: 137142.

Rodriguez-Trejo, D. A., Duryea, M. L., White, T. L., English, J. R., McGuire, J. (2003). Artificially regenerating longleaf pine in canopy gaps: initial survival and growth during a year of drought. Forest Ecology and Management 180: 25-36.

Rudolph, D. C., Conner, R. N. (1991). Cavity tree selection by Red-cockaded Woodpeckers in relation to tree age. Wilson Bulletin 103:458-467. 
Sargent, C. S. (1884). Report on the forests of North America. USDI Census Office, Washington, D. C. 612 p.

Soil Survey Staff, Natural Resources Conservation Service, United States Department of Agriculture. Official Soil Series Descriptions. Available online. Accessed $5 / 17 / 18$.

Sims, S. E., Hendricks, J. J., Mitchell, R. J., Kuehn, K. A., Pecot, S. D. (2007). Nitrogen decreases and precipitation increases ectomycorrhizal extrametrical mycelia production in a longleaf pine forest. Mycorrhiza 17: 299-309.

Thaxton, J. M., Platt, W. J. (2006). Small-scale fuel variation alters fire intensity and shrub abundance in a pine savanna. Ecology 87: 1331-1337.

U.S. Fish and Wildlife Service. (2003). Recovery plan for the red-cockaded woodpecker (Picoides borealis): second revision. U.S. Fish and Wildlife Service, Atlanta, GA. $296 \mathrm{pp}$.

Van Lear, D. H., Carrol, W. D., Kapeluck, P. R., Johnson, R. (2005). History and restoration of the longleaf pine-grassland ecosystem: Implications for species at risk. Forest Ecology and Management 211: 150-165.

Varner, J. M., Kane, J. M., Banwell, E. M., Kreye J. K. (2015). Flammability of litter from southeastern trees: a preliminary assessment. Holley, A. Gordon; Connor, Kristina F.; Haywood, James D., eds. 2015. Proceedings of the 17th biennial southern silvicultural research conference. e-Gen. Tech. Rep. SRS-203. Asheville, NC: U.S. Department of Agriculture, Forest Service, Southern Research Station. 551 p.

Varner, J. M., Kane, J. M., Hiers, J. K., Kreye, J. K., Veldman, J. W. (2016). Suites of fire-adapted traits of oaks in the southeastern USA: Multiple strategies for persistence. Fire Ecology 12(2): 48-64.

Vitousek, P. M., Howarth, R. W. (1991). Nitrogen limitation on land and in the sea: how can it occur? Biogeochemistry 13: 87-115.

Wade, D. D., Lundsford, J. D. (1989). A guide for prescribed fire in Southern Forests. USDA Forest Service Southern Region. Technical Publication R8-TP 11.

Wahlenberg, W.G. (1946). Longleaf Pine: its Use, Ecology, Regeneration, Protection, Growth and Management. CL. Pack Forestry Foundation and USDA Forest Service, Washington, DC, 429 pp. 
Walker, J. (1998). Ground layer vegetation in longleaf pine landscapes: an overview for restoration management. In: Proceedings of the Longleaf Pine Ecosystem Restoration Symposium. Longleaf Alliance Report no. 3, pp. 2-13.

Walker, L. C. (1995) "The Southern Pine Region." Regional Silviculture of the United States. Ed. John W. Barrett. Toronto: Wiley. Print.

Walters, J. R., Daniels, S. J., Carter, J. H., Doerr, P. D. (2002). Defining quality of redcockaded woodpecker foraging habitat based on habitat use and fitness. Journal of Wildlife Management 66: 1064-1082.

West, J. B., Espeleta, J. F., Donovan, L. A. (2004). Fine root production and turnover across a complex edaphic gradient of a Pinus palustris-Aristida stricta savanna ecosystem. Forest Ecology and Management 189: 397-406.

Wilson, J. B. (1988). The effect of initial advantage on the course of plant competition. Oikos 51: 19-24.

Wilson, C. A., Mitchell, R. J., Hendricks, J. J., Boring, L. R. (1999). Patterns and controls of ecosystem function in longleaf pine - wiregrass savannas. II. Nitrogen dynamics. Canadian Journal of Forest Research 29: 752-760. 
APPENDIX A

SUPPLEMENTARY BLOCK DATA 
Table A.1 Survival estimates by block.

\begin{tabular}{cccccccc} 
Effect & Block & Estimate & $\begin{array}{c}\text { Std Err } \\
\text { Pred }\end{array}$ & t Value & Pr $>|t|$ & Lower & Upper \\
\hline Block & 1 & 5.8105 & 4.0301 & 1.44 & 0.1522 & -2.1745 & 13.7955 \\
Block & 2 & 3.8645 & 3.9878 & 0.97 & 0.3346 & -4.0369 & 11.7659 \\
Block & 3 & 1.0212 & 3.9793 & 0.26 & 0.7979 & -6.8634 & 8.9057 \\
Block & 4 & 3.1388 & 4.0644 & 0.77 & 0.4416 & -4.9144 & 11.192 \\
Block & 5 & 8.3328 & 4.0451 & 2.06 & 0.0417 & 0.318 & 16.3477 \\
Block & 6 & 7.6607 & 4.0321 & 1.90 & 0.0600 & -0.3284 & 15.6499 \\
Block & 7 & -9.1358 & 4.0241 & -2.27 & 0.0251 & -17.109 & -1.1627 \\
Block & 8 & 3.3372 & 4.101 & 0.81 & 0.4175 & -4.7883 & 11.4628 \\
Block & 9 & -0.0536 & 4.0074 & -0.01 & 0.9893 & -7.9938 & 7.8865 \\
Block & 10 & -9.5458 & 4.0287 & -2.37 & 0.0195 & -17.528 & -1.5634 \\
Block & 11 & -8.7553 & 3.9702 & -2.21 & 0.0295 & -16.622 & -0.8889 \\
Block & 12 & -13.3280 & 4.0348 & -3.30 & 0.0013 & -21.322 & -5.3330 \\
Block & 13 & 0.0049 & 3.9736 & 0.00 & 0.9990 & -7.8684 & 7.8781 \\
Block & 14 & 3.1140 & 4.0000 & 0.78 & 0.4379 & -4.8114 & 11.0395 \\
Block & 15 & 4.5334 & 3.9959 & 1.13 & 0.2590 & -3.3840 & 12.4508 \\
\hline
\end{tabular}

Estimates for the random effect of Block by individual blocks for survival. 
Table A.2 Biomass estimates by block.

\begin{tabular}{cccccccc} 
Effect & Block & Estimate & $\begin{array}{c}\text { Std Err } \\
\text { Pred }\end{array}$ & t Value & Pr $>|t|$ & Lower & Upper \\
\hline Block & 1 & -0.1848 & 0.2926 & -0.63 & 0.5290 & -0.7647 & 0.3951 \\
Block & 2 & -0.5794 & 0.289 & -2.01 & 0.0474 & -1.1521 & -0.0068 \\
Block & 3 & 0.6312 & 0.2883 & 2.19 & 0.0307 & 0.05988 & 1.2026 \\
Block & 4 & 0.9782 & 0.2941 & 3.33 & 0.0012 & 0.3953 & 1.5611 \\
Block & 5 & 0.2175 & 0.2928 & 0.74 & 0.4591 & -0.3627 & 0.7977 \\
Block & 6 & 0.6236 & 0.2918 & 2.14 & 0.0348 & 0.0453 & 1.2018 \\
Block & 7 & 0.6525 & 0.2912 & 2.24 & 0.0271 & 0.0754 & 1.2295 \\
Block & 8 & -0.0631 & 0.2968 & -0.21 & 0.8322 & -0.6513 & 0.5252 \\
Block & 9 & -0.1506 & 0.2900 & -0.52 & 0.6046 & -0.7254 & 0.4242 \\
Block & 10 & -0.2415 & 0.2919 & -0.83 & 0.4098 & -0.8199 & 0.3369 \\
Block & 11 & -0.6590 & 0.3075 & -2.14 & 0.0343 & -1.2684 & -0.0496 \\
Block & 12 & -0.5234 & 0.2925 & -1.79 & 0.0762 & -1.1030 & 0.05616 \\
Block & 13 & -0.3088 & 0.2879 & -1.07 & 0.2859 & -0.8794 & 0.2618 \\
Block & 14 & -0.0846 & 0.2894 & -0.29 & 0.7706 & -0.6582 & 0.4890 \\
Block & 15 & -0.3078 & 0.2892 & -1.06 & 0.2896 & -0.8809 & 0.2653 \\
\hline
\end{tabular}

Estimates for the random effect of Block by individual blocks for biomass. 
Table A.3 BSNB infection estimates by block.

\begin{tabular}{cccccccc} 
Effect & Block & Estimate & $\begin{array}{c}\text { Std Err } \\
\text { Pred }\end{array}$ & t Value & Pr $>|t|$ & Lower & Upper \\
\hline Block & 1 & -12.5070 & 7.8427 & -1.59 & 0.1136 & -28.0460 & 3.0325 \\
Block & 2 & -15.0580 & 7.7655 & -1.94 & 0.0550 & -30.4450 & 0.3280 \\
Block & 3 & -17.0480 & 7.7513 & -2.20 & 0.0299 & -32.4060 & -1.6900 \\
Block & 4 & -18.2470 & 7.9087 & -2.31 & 0.0229 & -33.9170 & -2.5768 \\
Block & 5 & -23.3440 & 7.8732 & -2.97 & 0.0037 & -38.9440 & -7.7443 \\
Block & 6 & -19.9790 & 7.8506 & -2.54 & 0.0123 & -35.5340 & -4.4237 \\
Block & 7 & -0.6186 & 7.8300 & -0.08 & 0.9372 & -16.1330 & 14.8955 \\
Block & 8 & 0.4164 & 7.9754 & 0.05 & 0.9585 & -15.3860 & 16.2186 \\
Block & 9 & 26.5305 & 7.8033 & 3.40 & 0.0009 & 11.0692 & 41.9917 \\
Block & 10 & 6.5939 & 7.8418 & 0.84 & 0.4022 & -8.9436 & 22.1313 \\
Block & 11 & 25.9426 & 7.7345 & 3.35 & 0.0011 & 10.6178 & 41.2674 \\
Block & 12 & 18.4484 & 7.8544 & 2.35 & 0.0206 & 2.8859 & 34.0109 \\
Block & 13 & 17.5145 & 7.7409 & 2.26 & 0.0256 & 2.1769 & 32.8521 \\
Block & 14 & 21.0771 & 7.7875 & 2.71 & 0.0079 & 5.6471 & 36.5071 \\
Block & 15 & -9.7219 & 7.7818 & -1.25 & 0.2142 & -25.1410 & 5.6967 \\
\hline
\end{tabular}

Estimates for the random effect of Block by individual blocks for brown spot needle blight (BSNB) infection. 